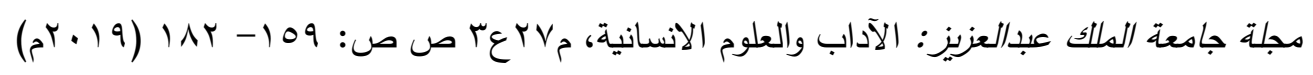

DOI:10.4197/Art.27-3.7

\title{
التكرار في شعر ابن عبد ربه دراسة فنيّة
}

\section{د. دليم ساعد السلمي

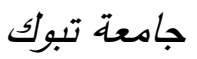

مستخلص. إن تتوع التكرار في شعر ابن عبد ربه ظاهرة لها أثرها القوي والفاعل في إبراز ملامح الثاعر

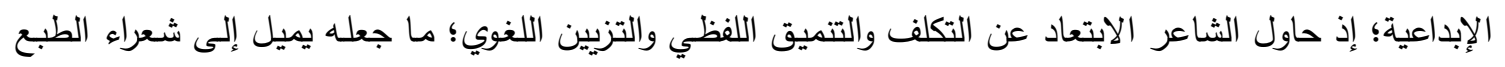

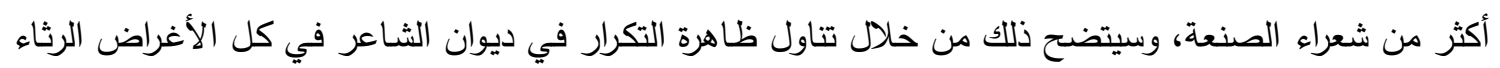

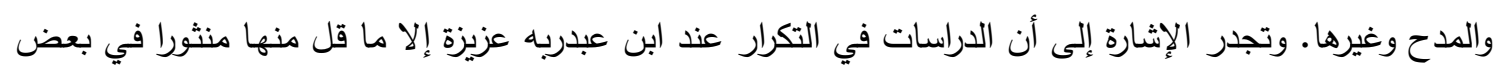

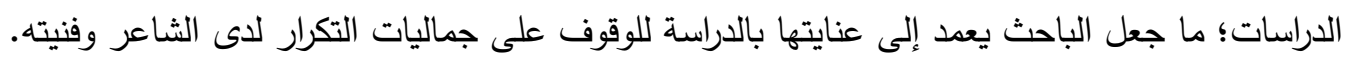

في اللغة العربية بين الحروف والجمل بنوعيها الاسمية والفعلية، وكذلك الألوان التكرارية الإيقاعية فيقصد بها إحداث نوع من الموسيقى اللفظية المؤثرة.

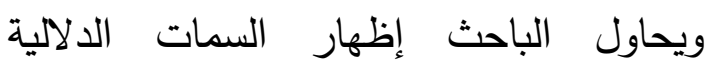
والجمالية للتكرار في شعر ابن عبد ربه ملتزما المنهج الوصفي التحليلي في الدراسة؛ لوصف بنفية بنية

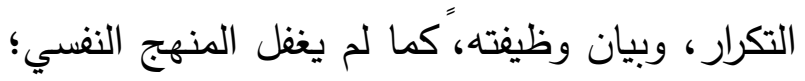
لارتباط التكرار بالعامل النفسي في كثير من حالات التجربة الشعرية لاى الثاعر • لإن

\section{مقدمة}

عرفت اللغة العربيّة ظاهرة التكرار كونها ظاهرة لغوية في أقدم نصوصها التي وصلت إلينا وردت في القرآن الكريم كلام الله المعجز، ممثلة في الثعر الجاهلي، ثم ، وكذللك وردت في الحديث النبوي الثريف، وكلام العرب، وقد حظي التكرار بعناية كبيرة في الدراسات اللسانية النصية الحديثة؛ لكونه ظاهرة بيانية تؤدي إلى الانسجام الداخلي؛ لأنه ليس

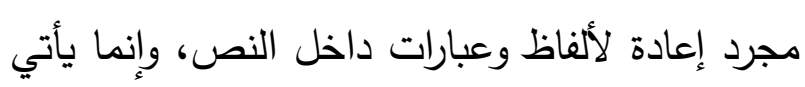
لمغزى وهدف وإلا صار عبثًا وعبئا، ويتتوع التكرار 
التكرار قديمًا وحديثًا: يُعد التكرار من الظواهر الاسلوبية التي تسخر لفهم

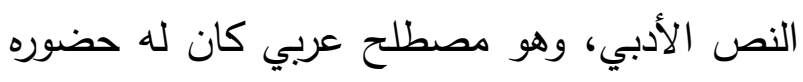
عند البلاغين العرب القدامى فتذكر معاجم اللغة من وهن معاني التكرار الإعادة والعطف والرجوع. فيقال: كرر الثيء تكريرا وتكرارًا، أعاده مرة بعد أخرى، والكر: الرجوع ويقال كررت عليه الحديث إذ رددته عليه، والكر مصدر كر عليه يكر وكرورا وتكرارا: عطف الف ليف عليه وكر عنه: رجع ... وكرر الثيء وكركره: أعاده مرة أخرى. "فالرجوع إلى الثيء وركع وإعادته

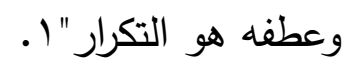

ويقول ابن سيده فى مخصصد: "والألف فى "

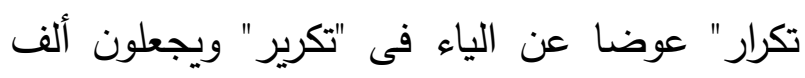
التكرار ، والترداد بمنزلة ياء تكرير وترديد" r. ومن خلال استقراء البحث للدلالة اللغوية لمادة لهرديل

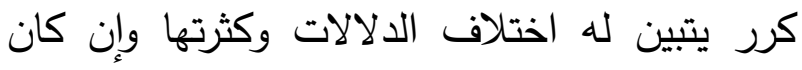

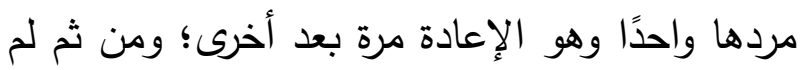
يتوقف العلماء القدماء منهم والمحدثون في نظرتهم ورؤيتهم للتكرار على كلمة سواء في تعريف التكرار

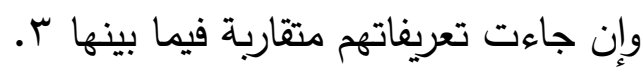

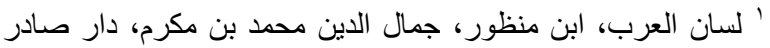

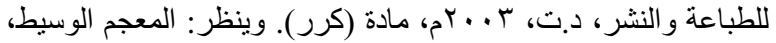

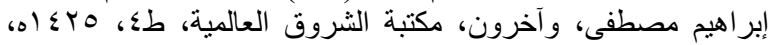

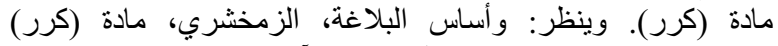

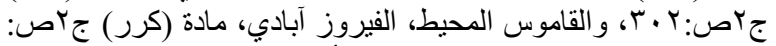

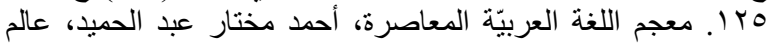

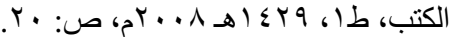

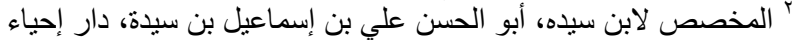

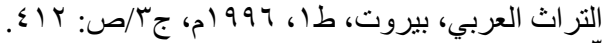

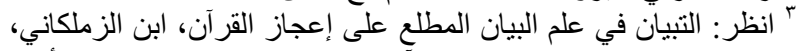

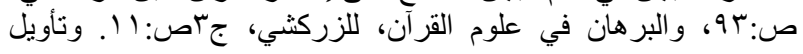

ومن يقرأ الدراسات السابقة القديمة والحديثة كابن خلكان وفيات الأعيان والمقري نفع الطيب أو الو غير ذللك من الكتب والدراسات التي عرضت ولات لابن عبد ربه، وك " تاريخ الأدب الأندلسي لإحسان عباس، و الأدب الأندلسي لأحمد هيكل وغيرهما من الدراسات يجدها تثير للتكرار في ثثاياها دون الوقوف أمامه بعناية وتحليل فني؛ ولما لم تتوفر لتبراير دراسة مستقلة تتناول التكرار في شعر ابن عبد ربه، فقد عمد الباحث لتذوق جماليات التكرار في شعر ابن عبدربه مستعينا بما سبقه من شذرات تجاه هذه

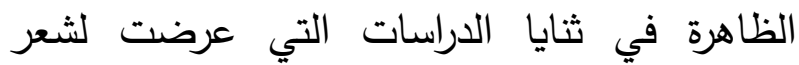
الثاعر؛ ومن ثم سيهتم البحث بمدى التجديد في استخدام التكرار عند ابن عبد ربه دلاليا وموسيقيا وجماليا من جهة تتبع لغته والجانب الموسيقى والصورة التي كونها التكرار •

وقد اقتضت الدراسة الخطة الدراسية الآتية: الجانب النظري: تتاول فيه الباحث نبذة مختصرة عن التكرار قديمًا وحديثًا، وعن أهمية التكرار

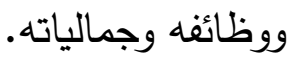
أما الجانب التطبيقي: وفيه يتتاول البحث نماذج تطبيقية للتكرار في شعر ابن عبد ربه من خلال ديوانه ومنها التكرار في الأسلوب. الخاتمة والنتائج: وتتضمن أبرز نتائج الدراسة

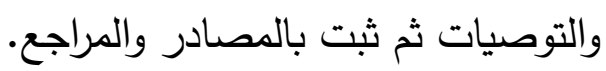


لغويا - وظائفها داخل النص - نصيا - والتكرار هو ظاهرة من ظواهر التماسلك النصي اهتم به الأقدمون كثيرا، فها هو الجاحظ يسميه "الترداد 9". وتعرفه المستشرقة بربرا جنستون كوتش بأنه: "الإقناع من خلال الصياغة وإلباسها إيقاعات نغمية متكررة جميلة تهدف إلى استمالة السامع". . 1. وعند إبراهيم محمود: تشاكل لغوي يلفت الانتباه ومظهر من مظاهر التماسك المعجمي مما يحقق ترابط النص وتماسكها ا. . ويقول الفقي: التكرار ضم الشيء إلى مثله في اللفظ كونه إياه في

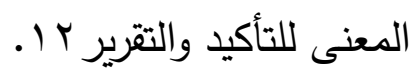
ومن العلماء من يفرق بين التكرار والإعادة كأبي هلال العسكري إذ يقول: "الفرق بين التكرار والإعادة: أن التكرار يقع على إعادة الشيء مرة وعلى إعادته مرات، أما الإعادة فتكون مرة واحدة، ثم يزيد الأمر وضوحا فيقول: ألا ترى أن قول القائل: أعاد فلان كذا، لا يفيد إلا إعادته مرة واحدة ،واذا قال كرر كذا ،كان كلامه مبهما لم يدر أعاده مرتين أو مرات ..... ولا يخلط بينهم إلا عامي لا يعرف الكلام"

` علم اللغة النصي بين النظرية والتطبيق، صبحي إبر اهيم الفقي، دار قباء

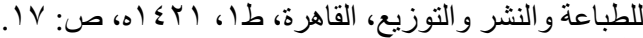

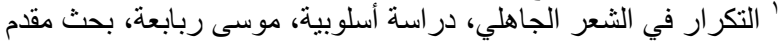

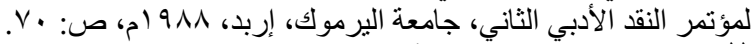

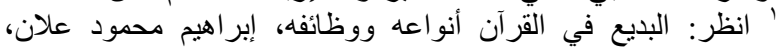

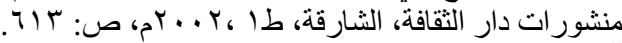

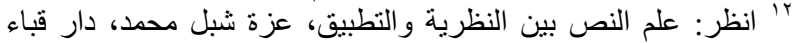

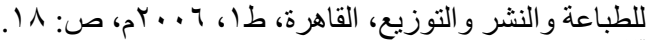

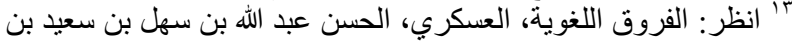

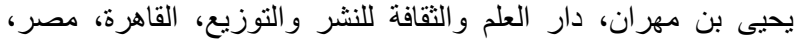

فالتكرار في الاصطلاح هو: إعادة عناصر

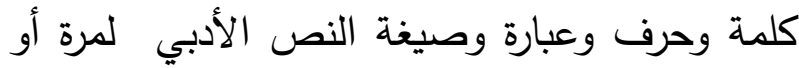

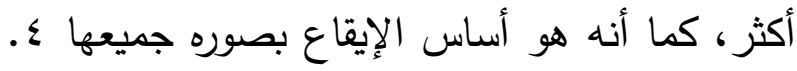

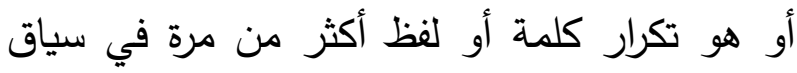

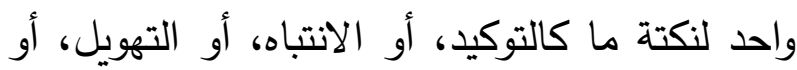

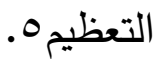

ويقترب ذللك من تعريف السجلماسي "التكرار" بعد أن يعطي معناه بأنه: " إعادة اللفظ الواحد بالعدد

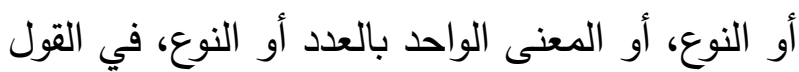

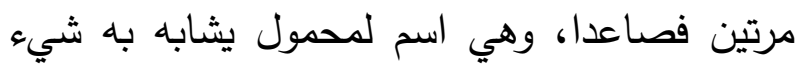

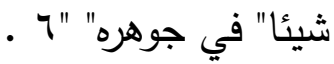

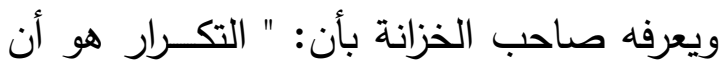
يكرر المتكلم اللفظة الواحدة باللفظ والمعنى"V. ويقول السيوطي من "أن التكرار هو التجديد للفظ الأول ويفيد ضربا من التأكيد".1 ويعرف صبحي إبراهيم الفقي التكرار بأنه: ظاهرة بيانية بوظيفة الربط على لئى مستوى البنية الظاهرة للنص المؤدية إلى الانسجام

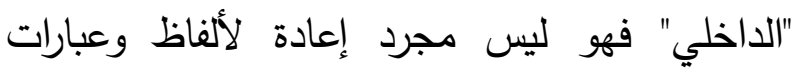
داخل النص؛ لكن هو العلاقة بين مفاهيم التكرار

مشكل القرآن، ابن قتيبة والصاحبي في فقه اللغة، ابن فارس، جا

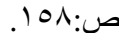
؛ انظر: معجم المصطلحات الأدبيّة، مجدي وهبه كامل المهندس، مكتبة

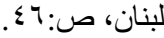

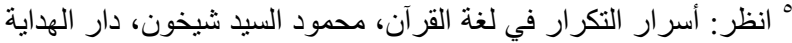

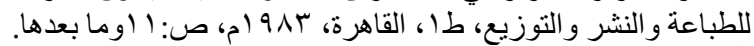

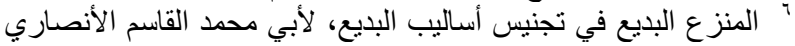

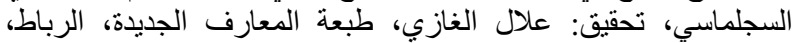

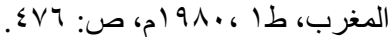

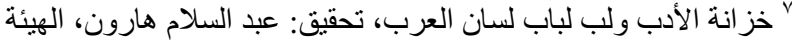

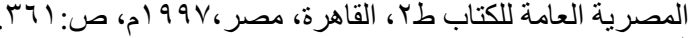

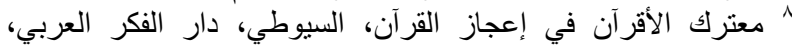


والتكرار أيضًا من الأساليب الثائعة في اللغة العربية كما مر وقد تعرض له الكثير من الباحثين

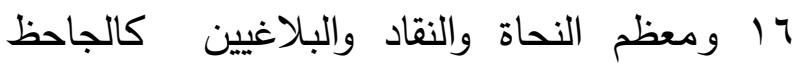
الذي ربط التكرار بالتأثير النفسي، أما ابن قتيبة وابن

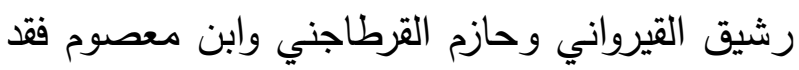

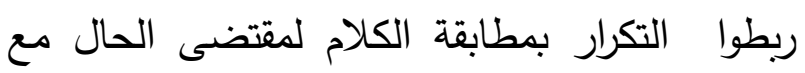

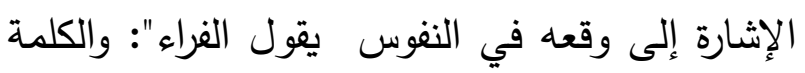

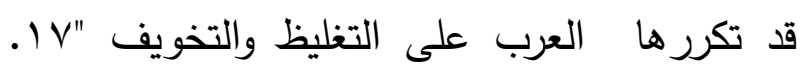
وكذللك قول ابن معصوم الذي عرف التكرار: بأنه

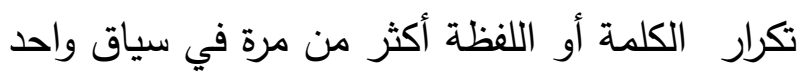

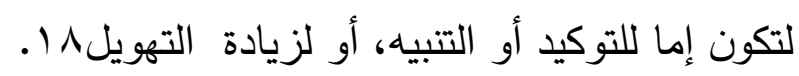
ويمكن للباحث القول بأن التكرار ليس ظاهرة لغوية فحسب؛ بل ظاهرة حيوية عامة موجودة في

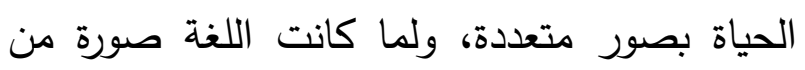

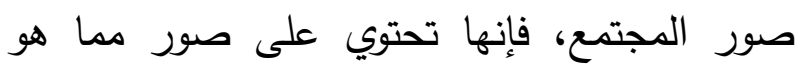
موجود فيه، فظاهرة كالترادف قد نجد لها شبها في هوري تشابه شخصين من البشر تثابها تاما يصعب معه

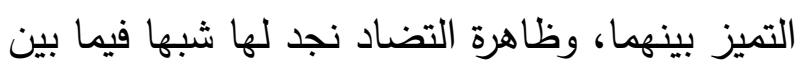
الأسود والأبيض من تضاد، وكذلك نحن في أفعالنا ونان وأقوالنا نكرر كثيرا، وعلى مستوى الدرس تلابط العلمي والعملي لا نكاد نجد عند النحاة والصرفيين كبير ولنيري الاهتمام بالظاهرة، كونهم يهتمون ببنية الكلمة

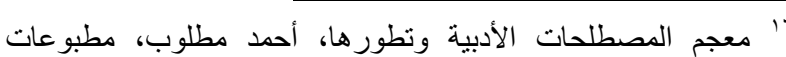

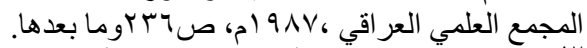

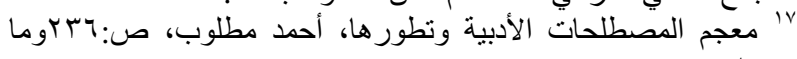

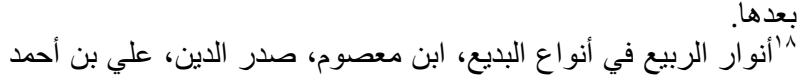

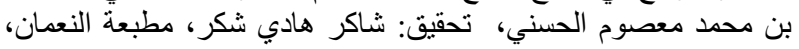

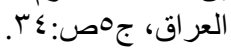

ويمكن للباحث الخروج بتعريف للتكرار بأنه: تماثل عناصر لغوية في مواضع مختلفة من العمل الفني، تكون أساسا للإيقاع بجميع صوره لإِقناع المتلقي. ومن الباحثين من ذكر التكرار في أبحاثه بمصطلح الترداد مستدلا بالجاحظ إذ يقول: "وجملة القول في الترداد أنه ليس فيه حد ينتهي إليه ولا

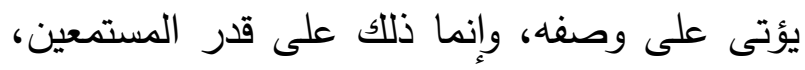

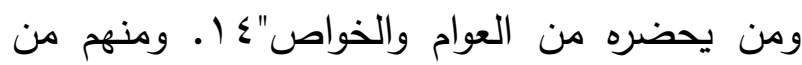

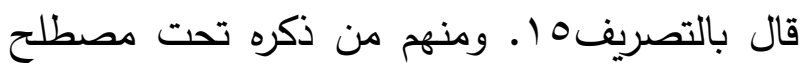

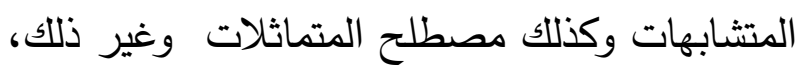
وكلها تدور في فلك بيان أن التكرار لا يقوم فقط وغئن على مجرد تكرار اللفظة في السياق، وإنما ما تتركه هذه اللفظة من أثر انفعالي في النفس؛ وبذلك يعكس

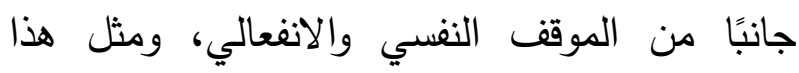
الجانب لا يمكن فهمه إلا من خلال دراسة التكرار بما يحمله في ثناياه من دلالات نفسية وانفعالية

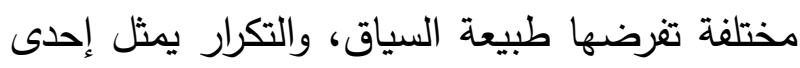
الأدوات الجماليّة التي تساعد على فهم مشهد، صورة أو موقف ما؛ بل ويعد التكرار من الأدوات الفنيّة للنص الأدبي شعره ونثره لغة وموسيقى وصورة

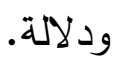

؛' البيان و التنبين، الجاحظ، تحقيق عبد السلام هارون، الخانجي، القاهرة،

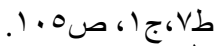
10 انظر: التصريف: في النظم القرآني دراسة بلاغية تأصيلية لمصطلح

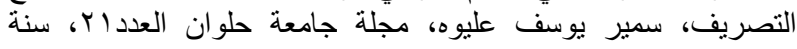

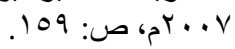


حتى ابن معصوم، فنرى مثلا الجاحظ يربط نكتة التكرار بنفسية المستمع، أو المتلقي اY . ويعد التكرار من علامات الجمال البارزة في فنون اللغة العربية وهو مصدر يدل على المبالغة من "الكر"، ويراد به التكثير في الأفعال، والتكرار بالمعنى العام "الإعادة"، ظاهرة في تتظيم الكون والوجود والطبيعة وجسم الانسان قبل ان تكون ظاهرة في الفنون المختلفة، فهو في الكون ماثل بوضوح في تكرار" دوران الافلاك وظهور النجوم والكواكب واختفائها "Yr؛ ومن ثم فالتكرار واحد من اهم القوانين التي تتظم الفعاليات الحيوية المختلفة لجسم الانسان؛ بل إن التكرار متمثل في الطبيعة بكل فنونها من تناوب الليل والنهار وغيرهما إذ نحسه في كل مكان وعلى جميع المستويات حيث تسلك الطبيعة مسلكا متموجا تعود من حيث بدأت في حلقات او دورات تتشابه بدرجات متفاوتةبr . وللتكرار علاقته الوثيقة بعلم النحو، إذ إنه أحد أهم صور التوكيد في اللغة العربية، ودرس التوكيد ضمن مباحث النحو كما هو معلوم، وبما أن الدراسات الأولى التي تتاولت القرآن الكريم اهتمت بنحوه وإعرابه، فمن الطبيعي أن تكون الإشارات الأولى للتكرار قد وردت في كتب النحو لاسيما في

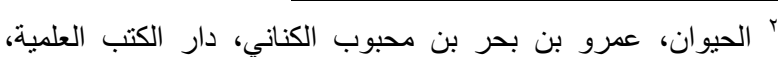

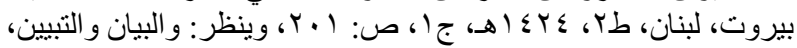

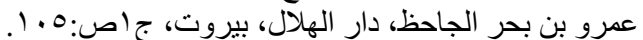

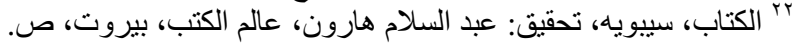
A 1 _Ar "rrr النقد الجمالي و أثره في النقد العربي، روز غريب، دار العلم للملايين،

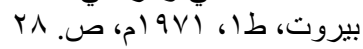

الواحدة، والنحو عندهم يهتم بتركيب الجملة، ولا يتجاوز ذللك عادة إلى النص كله؛ ولذللك اقتصر النحاة للتكرار غالبا على لون واحد منه هو ما اسموه

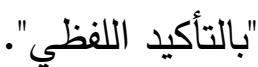
وملخص القول عن التكرار وشعريته عند القدماء فيرى البحث أن التكرار عندهم أحد أهم الأساليب التي بها اهتم القدماء وتحدثوا عنها بداية من الجاحظ وصولا لابن معصوم إذ ربطوا حديثهم عن التكرار بقضية اللفظ والمعنى وتفاوتوا في رؤيتهم عن التكرار باختلاف رؤيتهم عن اللفظ والمعنى، ومهما تفاوتوا فقد التقوا جميعهم في خدمتهم للقرآن الكريم والتوصل إلى إعجازه اللغوي والرد على المشككين ببلاغته. أهمية التكرار ووظائفه وجمالياته: يشكل التكرار ظاهرة أسلوبية في التعبير الأدبي عموما وبخاصة في الدراسات القرآنية9 ا. . وله أهميته في نفس المتلقي، إذ يعد من الأدوات الفنية للنص؛ لما يحدثه من آفاق التوقع ، كما يساعد في تحقيق وحدة العمل الفنية، ويبدأ من الحرف إلى الكلمة ثم العبارة • r. فتكمن بتلك النكت التي يقدمها التكرار في النص القرآني خاصة والنص الشعري عامة، وقد تعددت هذه النكت ونضجت منذ الجاحظ

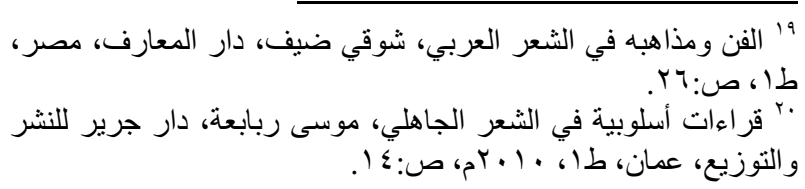


البسوس الشطر الأول " قربا مربط النعامة مني"YV"

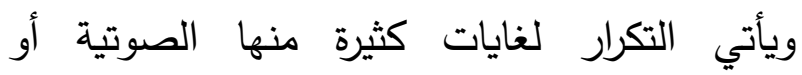
الموسيقية وهو ما يعرف بالأسلوبية الصوتية والتي لعيتي

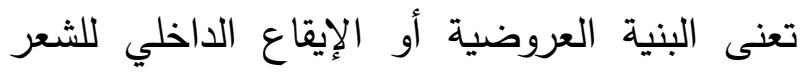

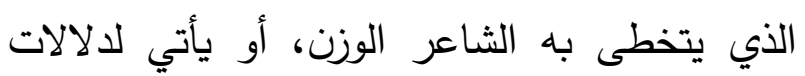

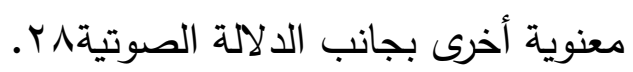

\section{ويؤدي التكرار وظائف منها:} الوظيفة التأكيدية: ويراد بها إثارة التوقع لدى لدى المتلقي، وتأكيد المعاني وترسيخها في ذهنه. الوظيفة الإيقاعية: فالتكرار ظاهرة موسيقية ومعنوية وتئية تقتضي الإتيان بلفظ متعلق بمعنى، ثم إعادة اللفظ

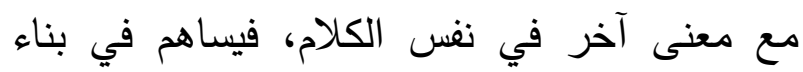
إيقاع داخلي يحقق انسجامًا موسيقيًا خاصًا. الوظيفة التزينية: وتكون بتكرار كلمة مختلفة في المعنى ومتفقة في البنية الصوتية، مما يضفي تلوينًا

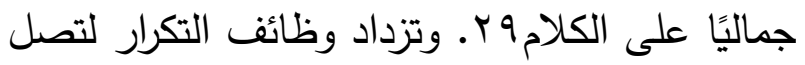
الكثير منها " العناية، والمبالغة، واختلاف المراد،

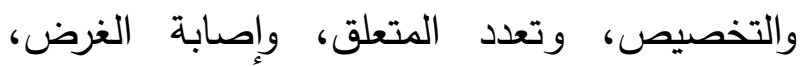

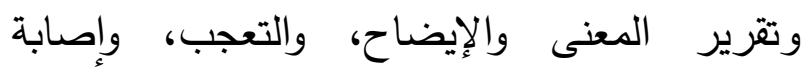

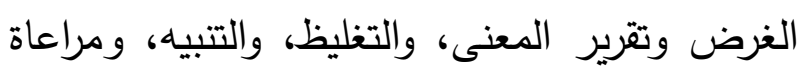

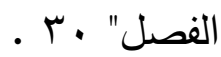

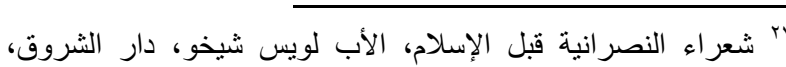

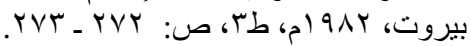

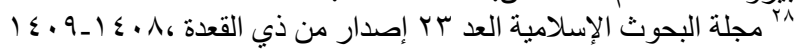

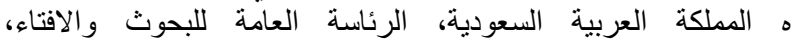
(ج) ra

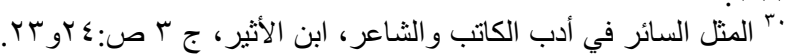

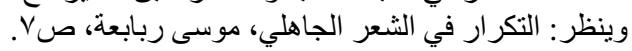

أولها - أعنى كتاب سيبويه - إذ عده ضربا من التوكيد لا يختلف عن "أجمعين" ونحوها وهي لفظة أنسابل

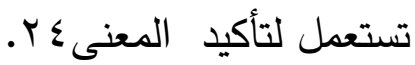
ومن يتدبر مؤلفات الجاحظ يجده قد تناول التكرار من زاوية تختلف اختلافًا واضحًا عن سابقيه مثل سيبويه والفراء مثلاً، ويرجع ذلك لتباين ثقافته

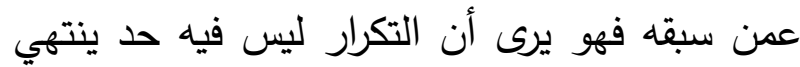
إليه ولا يؤتى على وضعه، وإنما ذللك على قدر المستمعين ووظيفته عنده الإفهام كما جاء في كتابيه البيان والتبين، والحيوانه؟؛ ومن ثم نجده ربط نكته وجمال التكرار بنفسية المتلقي أو المستمع.

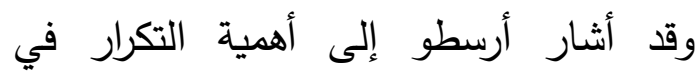
صناعة الجمال الفني إذ نجده قد وضع منذ القدم

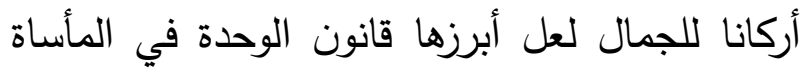
وتقوم أهمية الوحدة في أنها: "منها تتفرع باقي أركان الرهان

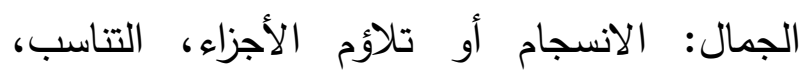
التوازن، التطور، التدرج، التقوية والتمركز، الترجيح

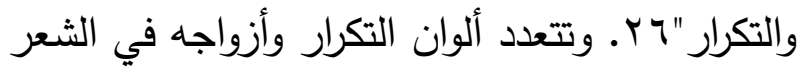
العربي بين تكرار الحرف والكلمة والتركيب أو ولئ

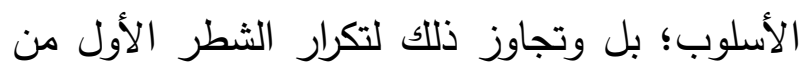

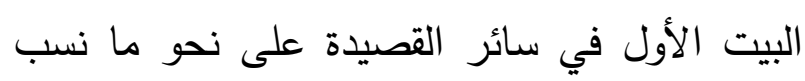
إلى الحارث بن عباد إذ كرر في قصيدته في حرب

كُ انظر: ثثلاث رسائل في اعجاز القرآن، تحقيق: محمد خلف ومحمد

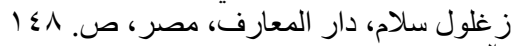

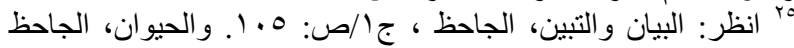

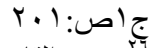

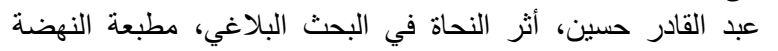

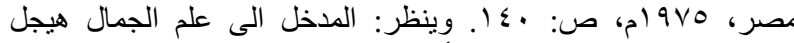

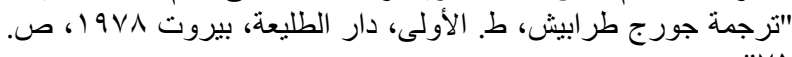


والإطناب بالتكرير والترديد والمجاورة ورد العجز

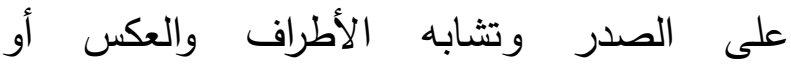

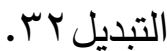

ويأتي التكرار في الدرس الحديث بكثرة في صور ومصطلحات متعددة. إذ ذكر النقاد الغربيون والعرب، بدءا من الثكلانيين الروس ،الذين امتدوا بالتكرار إلى الأجناس الأدبية المختلفة. وخصوا علم السرد به، وربطوه بالإيقاع والإنشاد، ثم كانت الته البه السيميائية وصو لا إلى جان كوهين بس. الذي طبق لإن مصطلح التكرار في مفهومه المحدد على دارسته

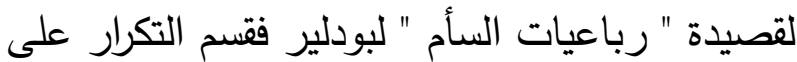
مستويات الصوت والتركيب والدلالة، وربط دلالة التكرار \& ب.. ، أما السيميائية فهنالك مصطلح يتماس وللتكرار استخدمته كأحد أشهر مقولاتها الإجرائية وهو "التشاكل" الذي قال به "جريماس" وقد حدده بأنه" تكرار مقنن لوحدات الدال( ظاهرة أو غير فاله

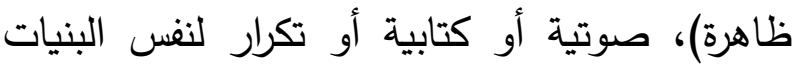
التركيبية( عميقة أو سطحية)" هب، وفي الدراسات الأسلوبية يتداعى "التكرار" بوصفه ظاهرة أسلوبية

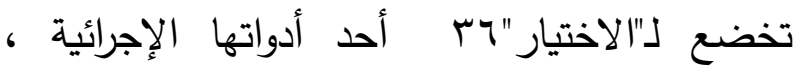

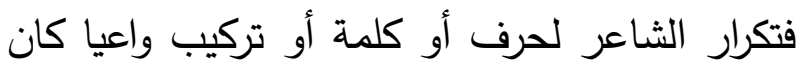
أو غير واع رهن باختياره لما يناسب شعوره ونفسيته

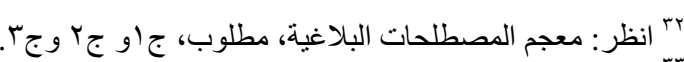

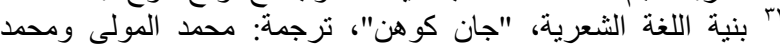

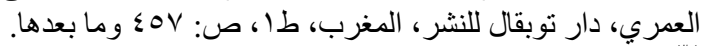

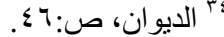
roro تحليل الخطاب الثعري"استر اتيجية التناص"، محمد العمري، المركز

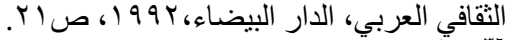

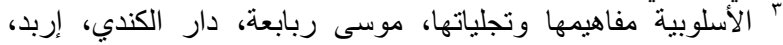

الوظيفة الحجاجية: وتكون بتكرار بعض الأدوات

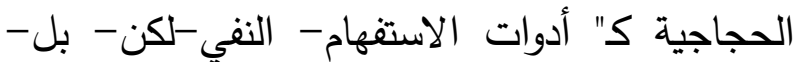
حتى - النفي والاستثناء... ، وتلك الأدوات تسمى الأس عوامل حجاجية لأنها تحمل طاقة تأثيرية قوية ترمي التأثير في المتلقي وتعمل على استمالته" ابه هكذا ظهر التكرار في الدرس القديم، إذ تفاوت هؤلاء في حديثهم عنه؛ ولكنهم اجتمعوا في دافع بحثهم عنه وفي تتبهـم للغرض الذي قد يؤديه. وقد أشاروا إلى تفاوت الأغراض التي يؤديها التكرار وكانت هذه الأغراض أو النكت مرتبطة بالمبدع أو المتلقي فالتكرار صدر عن قصد عند المبدع فهو إلحاح لغرض دون غيره كما يقصد من التكرار أن يؤدي دورا في نفس المتلقي إذ يستفزه

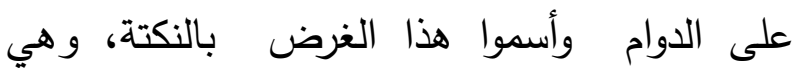
جوهر الثعرية، فالتكرار كان خرقا لمألوف استخدام اللغة، و هذا الخرق ما كان إلا لنكتة، وهذه النكتة

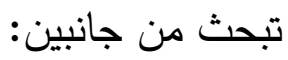
- - جانب المبدع، إذ يبحث الدارس في النكتة

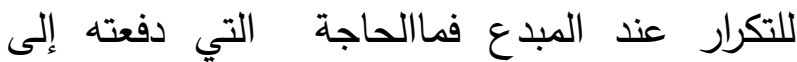
تشكيل لغته تشكيلا قائما على التكرار؟. - جانب المتلقي، إذ يبحث الدارس في النكتة التي لماني تولدت عند المتلقي وتختلف هذه النكتة من متلق إلى آخر • هذا وقد ارتبط التكرار بمجموعة من لن لهن المحسنات اللفظية من مثل التكرار الخالص

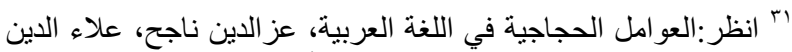

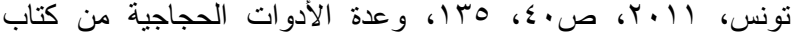

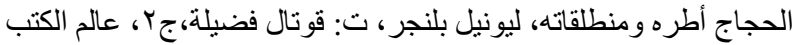

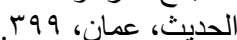


وهنالك من جعل التكرار أداة لتصوير حالة نفسية دقيقة أو مجرى اللاشعور من إنسان مأزوم حيث يتعلق وعي الإنسان في لحظات المحن والأزمات بكلمة أو صورة أو موقف استرعان عالها وعيه من الماضي أو طرقت ذهنه في هذه الحظات وكأنما تهبط بعد ذللك اللاشعور وتبقى حبيسة فيه فترة من فن فه فه الزمان لتطفو إلى الوعي بين الحين والحين ويتردد

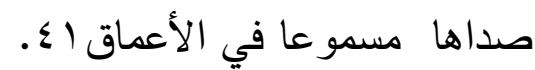
وملخص القول، تكمن جمالية وشعرية التكرار في

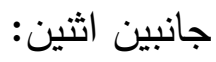
أولهما: عند مبدع الكلام الذي خرق مألوف اللغة حين استخدم التكرار لنكتة أو لغاية في أعماقه،

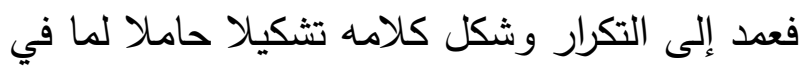

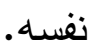

وثانيهما: عند متلقي الكلام الذي استقز من هذا

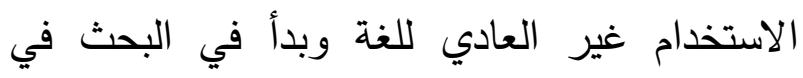
دلالة التكرار وغايته ليقف عند ما وارء اللفظة وما

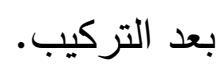

ويستخلص من التكرار الكثير من الدلالات وفيه

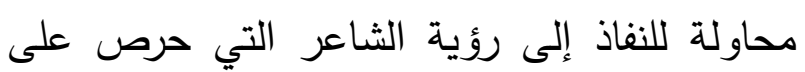
بثها في شعرهوجعل التكرار حمالا لها.

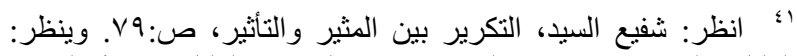
الهليل، التكرار في شعر الخنساء، عبد الرحمن الهليل، مكتبة المؤيد، والئه

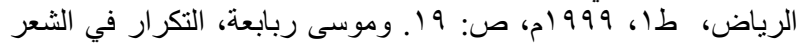

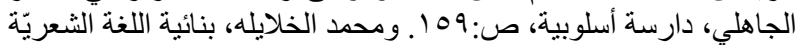

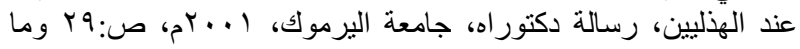

والفكرة التي يعبر عنها، كما أن مصطلح " الكلمات

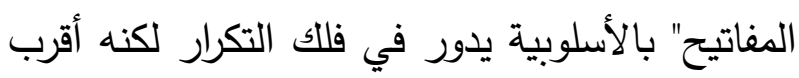

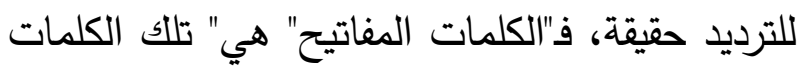
المعجمية التي يزيد تكرارها من دلالتها فوق ما يكون

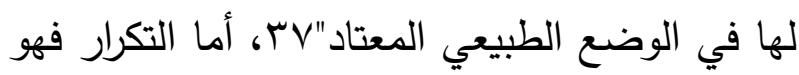
أقرب بل هو يندرج تحت " الاتساق المعجمي" الذي لهي

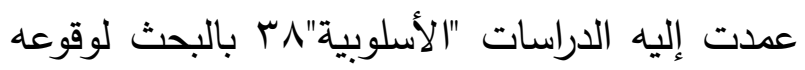

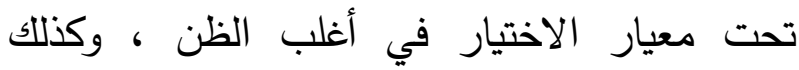
تدرجه "اللسانيات النصية" تحت "الاتساق المعجمي"، ولابد لظاهرة التكرار من دور فاعل في نظريات

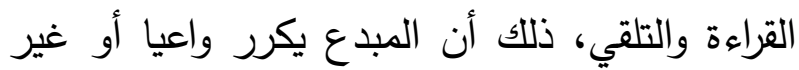
واع ثم يأتي دور المتلقي لفهم وظيفية التكرار وجمالياته في النص بموقعه آخذا دوره في عملية القراءة أو بالأحرى التأويل، ذلك "أن الظاهرة الأدبية

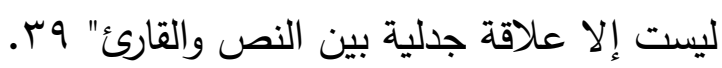

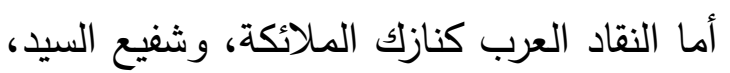

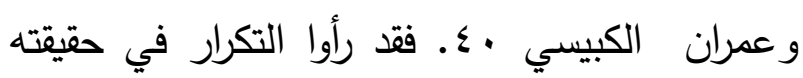
إلحاحا على جهة مهمة في العبارة يعني بها الثاعر أكثر من عنايته بسواها ويكثف التكرار عن اهتمام

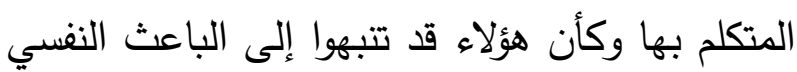
للتكرار •

rV الأسلوبية الرؤية والتطبيق، يوسف أبو العدوس، دار المسيرة، عمان، 1999. I. PV

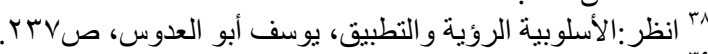

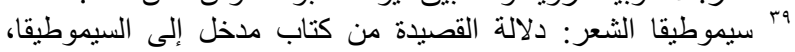

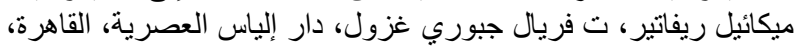

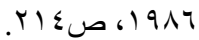

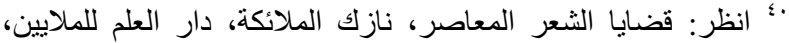

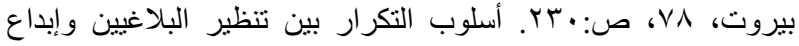

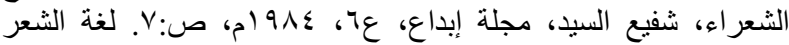

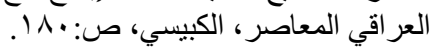


وقوله في وصف الخمر 7 ؛؟:

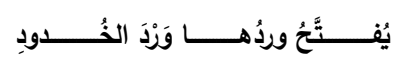

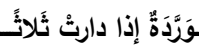

وقوله في معنى الثباب V ؛ :

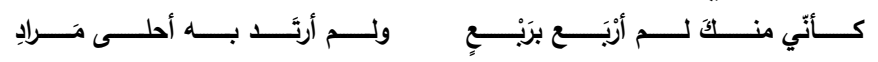

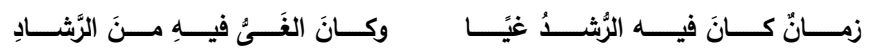
وقولـه في معنسي الصـبر والإقدام في الحـرب، وذكر القائد أحمد بن محمد بن أبي عَبدة ^^ء :

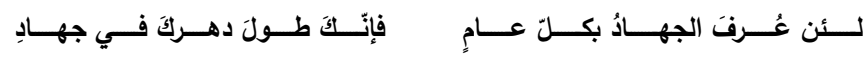

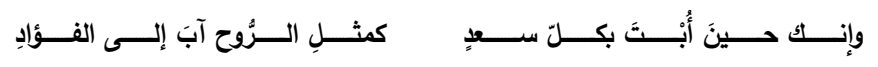

$$
\text { وقوله في معنى الثيب 9 ؛ : }
$$

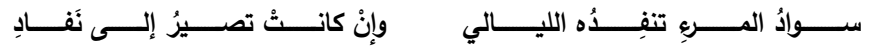

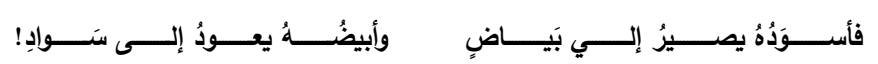
وقوله في رثاء ابنه ، 0 :

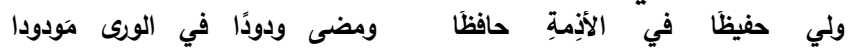

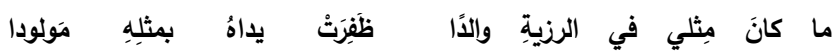

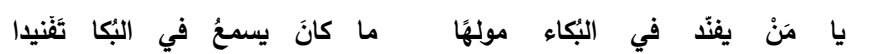

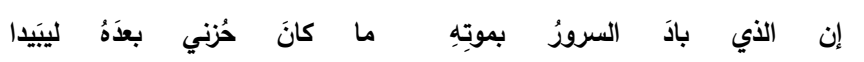
وقوله

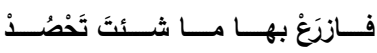

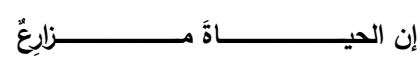

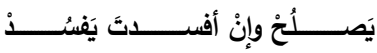
لَحْتَهُ

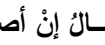
وقوله
ـ تكرار المفردات و التكرار الاثتقاقي: ويعد هذا اللون من أبسط ألوان التكرار، ويشتمل على تكرار كلمة واحدة، والديوان مليء وغني بهذا اللون من التكرار؛ لأنه غالبا ما يعبر عن حالة الشاعر النفسية، أما التكرار الاشتقاقي فيتمثل في تكرار كلمات ذات جذر لغوي واحد والقائم على تثقيق البنية الصرفية إلى صيخ مختلفة للدلالة على معان مختلفة.

قـال ابـن عبدربـه في معنى خدمـة السـطان وصحبته

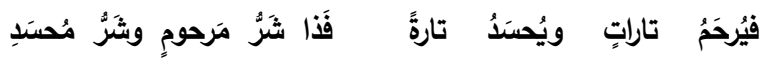

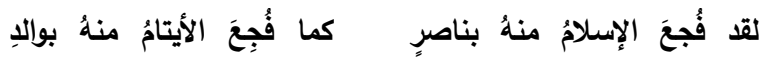
وقـال ابـن عبدربـه في معنـى المبـادرة بالعمـل الصالح، وفي ذكر الموت ئ :

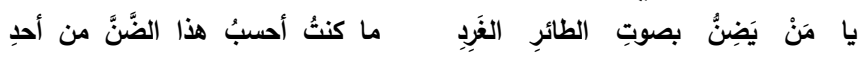

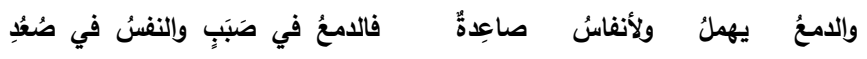
وقـال ابـن عبدربـه فـي الناصـر لـدين اللهيـوم البيعة له في قرطبة؛؛ ؛

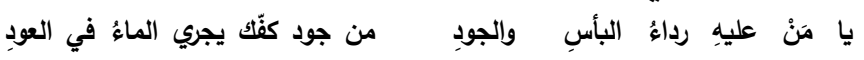
لما تطلعتَ في يوم الخميسِ لنا والناسُ حولك في عيدٍ بلا عيدا!

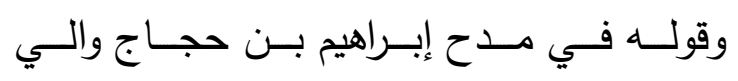

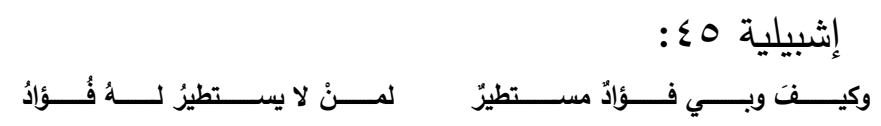

ז؛ الديوان، تحقيق: محمد رضوان الداية، مؤسسة الرسالة للطباعة و النشر

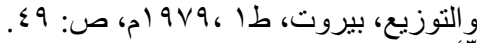

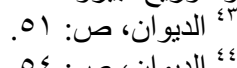

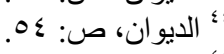

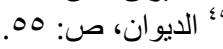


ورصدها في البيت الشعري هو عدول أو كما يسمونه

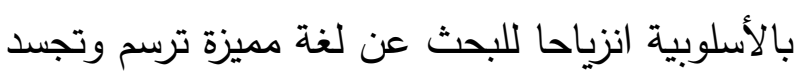
تجربة الثاعر تصبغه بصبغة خاصة تميزه عن

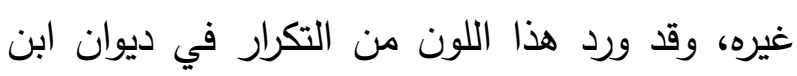
عبدربه وسيذكر البحث نماذج منها دون الخوض في وني جماليات وفنية هذا اللون خوفا من الإطالة. وسيقتصر هذا البحث على لون من ألوان

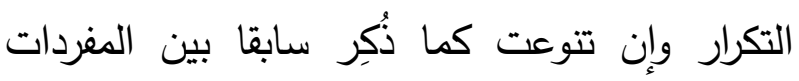
والاشتقاقات والمجانسة والأساليب في شعر ابن عبد تكران

$$
\text { ربه، وهو تكرار الأسلوب، كما سيأتي: }
$$

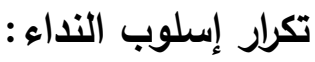

جاء أسلوب النداء في قصيدة رثاء ابن عبد

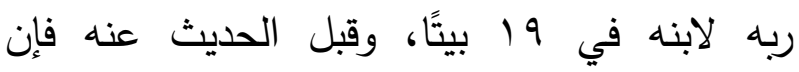
الحروف قد تكررت فكان حرف اللام صاحب المرتبة الأولى "له السبق "إذ تكرر في القصيدة Vآمرة، بعده

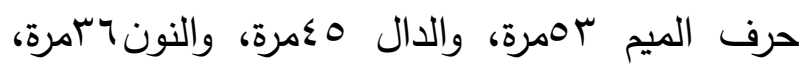

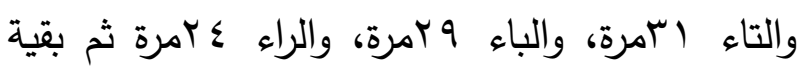
الحروف، بجانب حروف الدد الألف والواو والياء

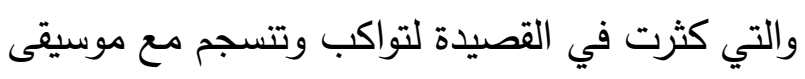
الحزن، وكان روي القصيدة حرف الدال وهو من هن هوني حروف القلقلة والذي يجسد القلق والاضطراب والصراع الداخلي للشاعر لفقده ولده. وقد أدّى تكرار حرف الدال كروي للقصيدة دورًا واضحًا وكبيرًا في الموسيقى الخارجية والداخلية؛ إذ أفاد بوجود ملامح صوتية في الشعر كتكرار الكلمة نفسها أو لإحدى أخواتها من الجذر الواحد فئ في التعرد

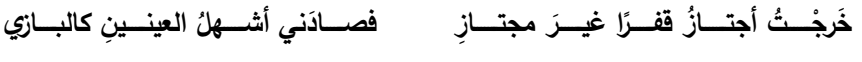

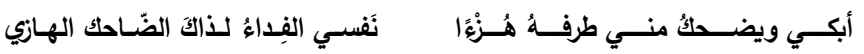
وقوله

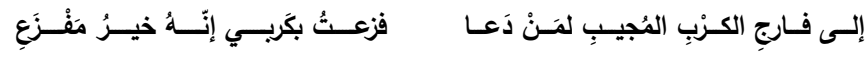

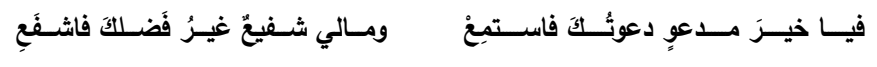
وبالإضافة إلى ما يقوم به هذا التكرار من وظيفة إيحائية تكسب المعنى قوة وتساعد في إبراز فكرة الثاعر وتسليط الضوء على ما يريد إيصاله للقارئ، يعطي إيقاعا موسيقيا يساعد على إظهار وتجسيد وتشخيص أحاسيس الثاعر وعواطفه.

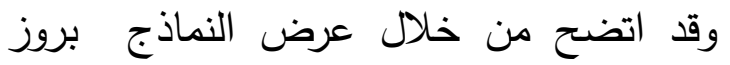
ظاهرة التكرار في الديوان؛ إذ اتخذ منها الثاعر عرص الثراج

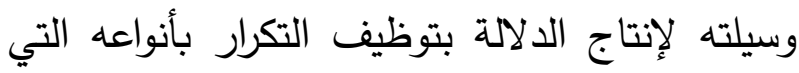
ذكرناها، مما يعمق إلحاح الثاعر على فكرته لإنه وعرضها بأساليب متنوعة مختلفة، مما يثد انتباه لعماه المتلقي، فيدفعه إلى تغيير منحاه الفكري والعقلي؛ وذللك لأن التكرار يغني المعنى ويؤصله؛ مما يجعل له دورا بارزا في إنتاج الدلالة وإثراء المضمون لهني الفكري فضلا عن الإثراء الإيقاعي الذي يعمق تأثر

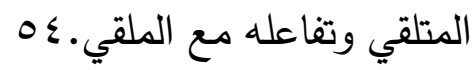
استعمل الثاعر نمطًا من التكرار يتمثل في هي التكرار الاشتقاقي والذي يعتمد على مصاحبة الألفاظ ذات الاشتقاق الواحد؛ إذ إن اشتقاق الدفردات

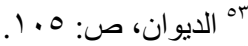

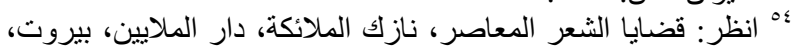

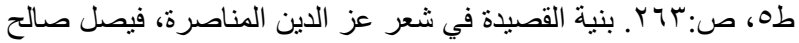

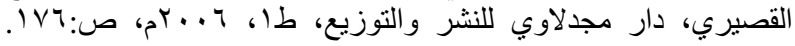
القصيدة العربية الحديثة بين البنية الدلالية و البنية الإيقاعية، محمد صابر صابر

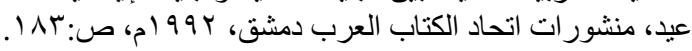


وقد استعمل الثاعر النداء بأنماط كثيرة فضلاً عن استعماله الندبة والاستغاثة، كما رأينا ابن عبد ربه ينحرف بالنداء من وجهته النحوية التي ركز عليها النحويون إلى وجهةٍ جديدة يجسد بهما مشاعره ومعاناته وتجربته بصدق لا يوجد عند أحد من الشعراء، إذ أفاد الثاعر من النداء دلالات بلاغية كثيرة وكانت هي الغاية من النداء عنده، وليس المعنى النحوي للنداء وهو طلب تتبيه

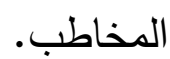

فالنداء علامة من علامات الاتصال بين الناس، وهو دليل قوي على اجتماعية اللغة؛ ومن ثم فهو كثير الاستعمال، ولا يكاد يخلو كلام إنسان كل

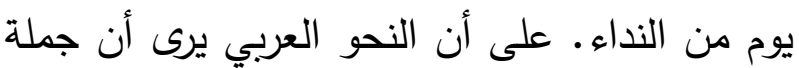
النداء جمل تامة شأنها شأن الجمل الأخرى يتوافر

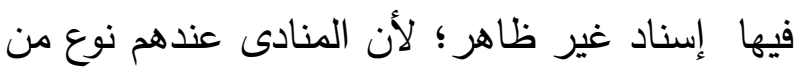
المفعول به وهو منصوب بفعل محذوف تقديره: أنادي أو أدعو، وهذا الفعل لا يظهر مطلقا، وينوب عنه حرف النداء ويعمل عمله، وحروف النداء سبع،

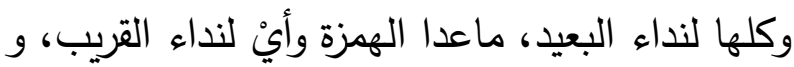
"وا "للندبة وهو المتفجع عليه أو المتوجع منه و "يا" أكثر حروف النداء استعملا فهو أصل حروف النداء ؛ولذلك لا يقدر غيره عند حذف حرف النداء ولكونه

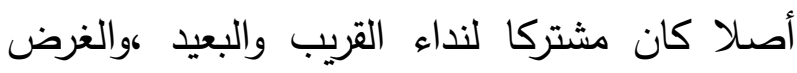
الرئيس من أسلوب النداء التتبيه والاهتمام بمضمون الخطاب ؛لأن النداء يسترعي إسماع المنادين.
سواء كان على سبيل التجانس الاشتقاقي أو التقابل أو التضاد يرتبط ذلك بعاطفة الشاعر الحزينة؛ لأن الجانب الصوتي أو الإيقاع الصوتي له أثر واضح

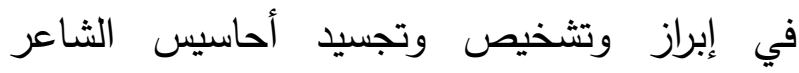
وانفعالاته ومشاعره؛ ولكي يتضح ذللك سيقوم الباحث بتحليل صوتي وصرفي ونحوي وبلاغي للرثاء لاى الشاعر مبينا ومثبتا أثر ذلك في الدلالة في قصيدته في رثاء ولده التي قال في مطلعهاهـ:

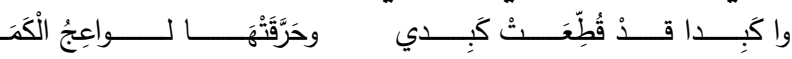

فقبل الخوض في أسلوب النداء عند ابن عبد ربه كان لزاما على الباحث أن يذكر بعضا من دلالات النداء لاى السابقين والمحثين إذ يكادون يتققون على دلالاته وسيقوم هذا البحث بدراسة

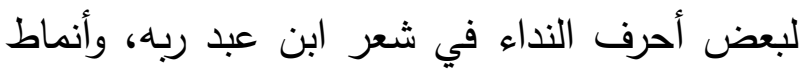
استعمالها، وعرض تحليل أسلوب النداء في شعره دلاليا ونحويا وأسلوبيا مستعينا ببحوث النحويين والبلاغيين والدارسين المعاصرين مستهديا بالقرآن الكريم وبالشعر العربي الذي أجاز النحويون الاستثهاد به؛ بغية الوقوف على ما أضافه النداء

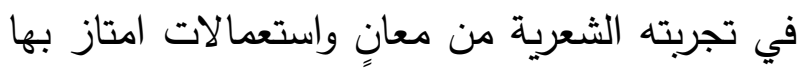
في ديوانه، فالنداء بادرةٌ غريزية يمارسها الإنسان والحيوان تلبية لحاجاته الفطرية، وقد ابتكر الشعراء

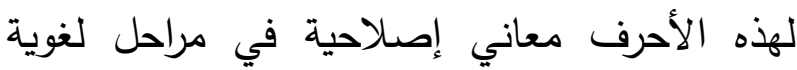

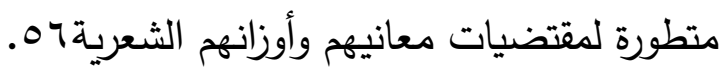

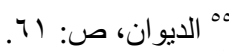

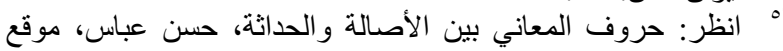

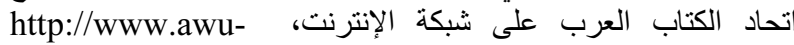

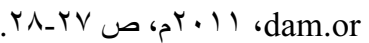




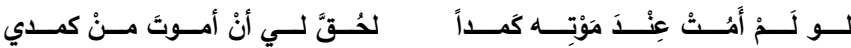

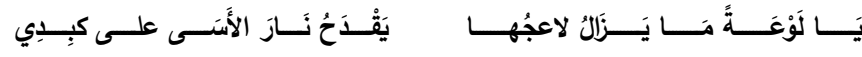
بدأ الثاعر قصيدته عادلا عن النداء الأصلي المعتاد إلى أسلوب النداء المفيد للندبة الدال على

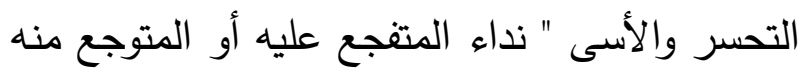

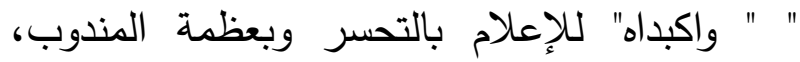

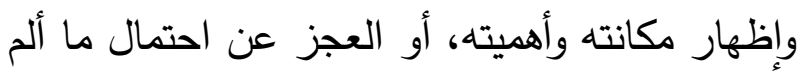

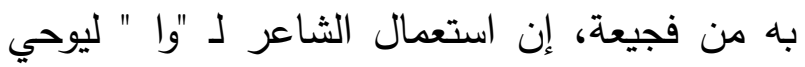

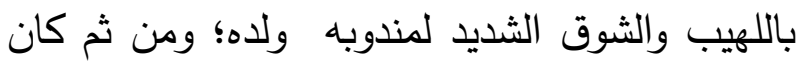
التعبير بالندبة رفعا لصوت الثاعر تعبيرا عما في نفسه من الجزع والألم والتأسف من فقد ولده فصاح "واكبدا"، ولو ربطنا بين اللغة وعلم النفس وجدنا أن أسلوب الندبة "واكبدا" يجسد إحساس الأب "الوالد" وشعوره وعاطفته الحزينة لفقد ولده فصرخ من داخله

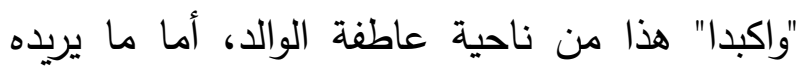

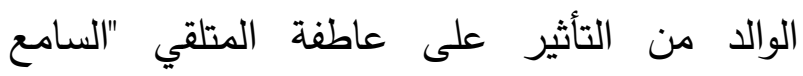
والقارئ" فقد أثار وأثر في المتلقي ليشاركه فجيعته

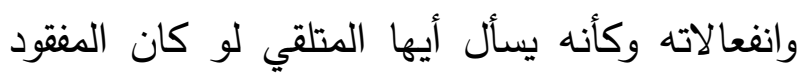

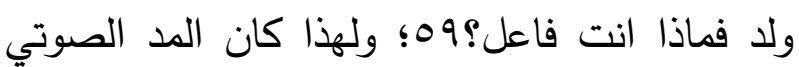
في التعبير "وا" الدالة على الندبة موحيا بالاتساع والامتداد في الشعور الحزين والانفعال الممتد لفقد بلد

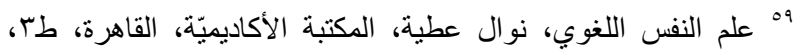

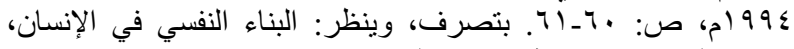

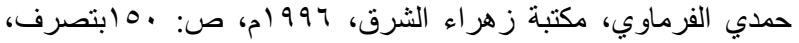

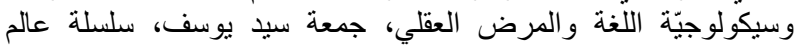

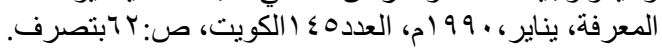

وهذه بعض من أغراض النداء OV.

الإغراء والاختصاص والاستغاثة والندبة

والزجر والوعيد والتتبيه والتحسر والتذكر وغالبا ما الإعراه

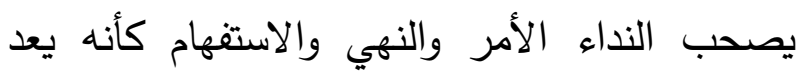
النفوس ويقيئوها فتتقوى به وقد تجمع هذه الأساليب كلها؛ وبهذا لم يتوقف أسلوب النداء عند الحدود

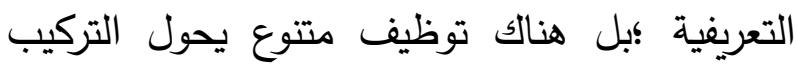
اللغوي النحوي والدلالي عن بنيته المباشرة تحويلات إيحائية تستوحى من السياق، وتستخلصها العقول والقرائح من القرائن الدالة عليه، في قوله هـ 0 :

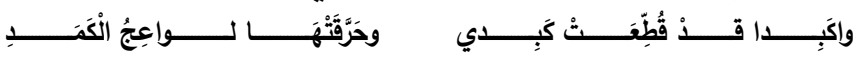

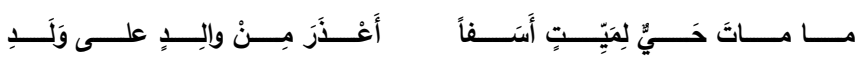

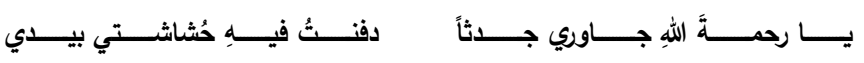

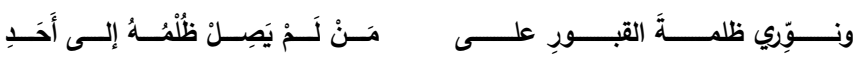

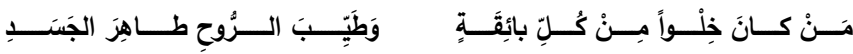

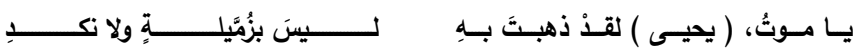

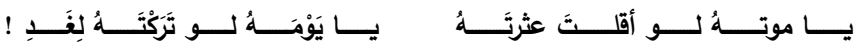

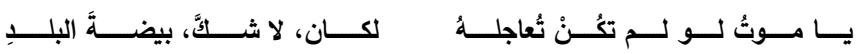

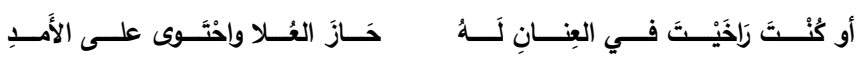

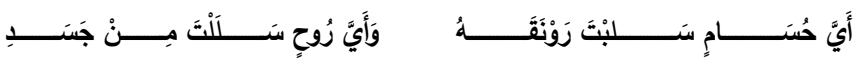

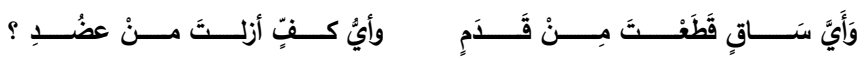

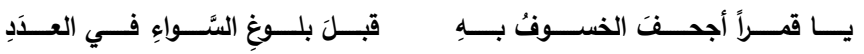

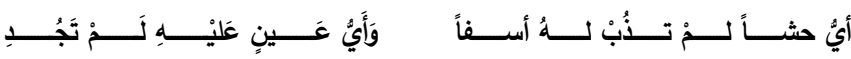

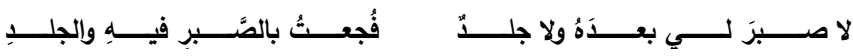

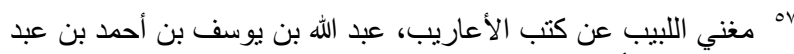

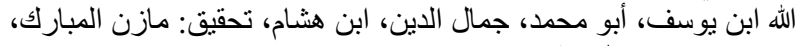

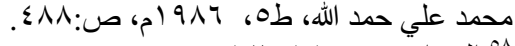

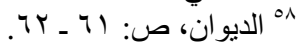


يعاني منه وبين الجانب الشكلي للتجربة الفنية؛ ومن ثم كان أسلوب الندبة أسرع من غيره في التعبير عن ذللك؛ مما قدم تجربة فنية جمالية فريدة. فحركة النغس الشجية المتدافعة من شدة الحزن والأسى تموت بالصوت المنبعث من أعماق الحلق حتى تخرج من من

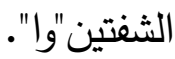

فالقيمة الجمالية لهذا النمط من أساليب النداء لا لاءل تتبع من العناصر الفنية المكتملة في الصورة فقط وإنمّا تتبثق من التصوير المجازي المرتبط بمشاعر أصحابه، ومن إرسائه في نُفوسنا.. ولهذا فنحن نحس بملامح التجربة الذاتية في إطار جمالي مثير، وهذا ما نجده في أسلوب الندب، ونترك العدول بالندبة في النداء إلى النداء نفسه لنرى كيف وظف الشاعر هذا الأسلوب اللغوي في تجسيد وتشخيص مصييته،

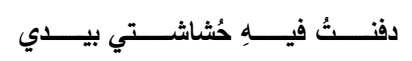

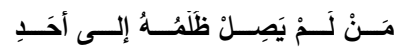

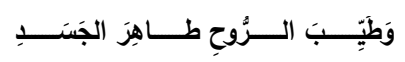

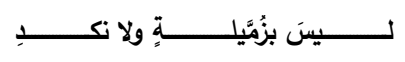

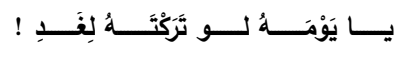

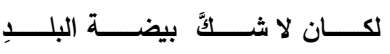

\section{فيقول الثاعر الج:}
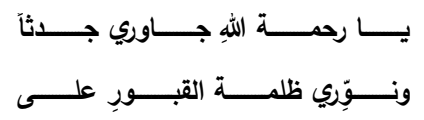

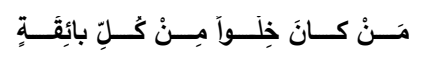

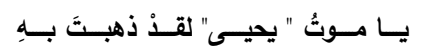

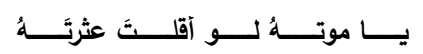

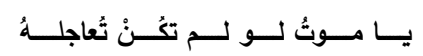

أول ما يلاحظه الباحث حرف النداء المكون من "الياء والألف" وهما حرفا علة؛ وباجتماعهما يتسع الصوت وتعلو الموسيقى الإيقاعية مما يثير انتباه المتلقي لما يأتي بعدها، فنراه ينادي الرحمة " يا رحمة الله" ويضيفها إلى الله تعظيما لشأنها كعظيم فجيعته طالبا منها "بصيغة الأمر "جاوري" قبر ولدي
إن افتتاح الشاعر قصيدته بأسلوب الندبة" وا" ليبرز عاطفة الشاعر وانفعالته الوجدانية وغليانها وهي أمور معنوية غير محسوسة للمتلقي في لوحة محشوة مجسمة ومشخصة أمام المتلقي في جرسها الصوتي العال والإيقاع الممتد من البكاء والعويل والصراخ والنواح.

إذا أرجعت بصر التدبر في البيت كرة أخرى انقلب إليك بما يحمله تعبيره " واكبدا" من دلالات مكثفة من الحزن الثثيل، أليس الأولاد فلذات الأكباد ؟ فهو إذن صراخ المصاب والمفجوع، وصوت الداخل لا الخارج فالألم داخلي والنزف من الكبد فالألم أشد وأقتل ،وحين نسير رويدا في البيت نجد أن هذا الجزء المصاب لم يصب فحسب بل تقطع وكأن الشاعر بأسلوب المبالغة من خلال الفعل المشدد "تقطع" أن يشعرنا أن كبده لا سبيل لعودتها ثانية لحياة أخرى طبيعية، وذلك حين أضاف إلى لى هذه الأجزاء المتناثرة نارا تحرقها من لواعج هذا الفقد • 7.

هذا المطلع يموج بالدلالة المكثفة منذ كلمة الافتتاح "واكبدا" إلى منتهاه "الكمد" ويطلعنا بصدق لع مصاب الشاعر الجلل بابنه لفقيد. وقد جاء أسلوب الندبة لدى الشاعر مفتاحاً للتفريخ والتقريج عن مشاعره الحزينة؛ ولذلك حوَّل الشاعر الصيغة اللغوية إليه؛ ليقيم التناسب بين ما

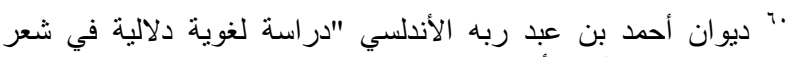

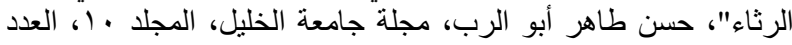

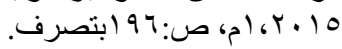


ثـــ ينقــلـل نـــداءه وخطابـــهـ للمــوت نفســـه

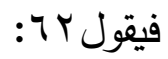

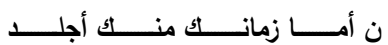

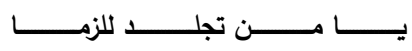

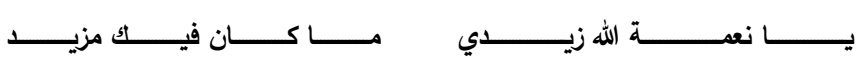

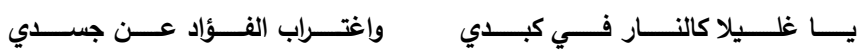

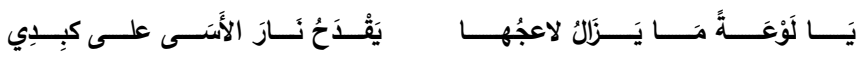

"يـا مـوت يحيـى"، "يـا موتـه " "يـا يومـهـ" "يـا مـوت "

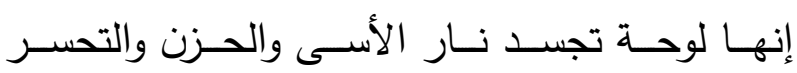
الملتهبـة بـداخل الوالـــــــرزه في صـوت البكـاء

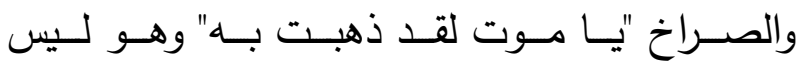
بزميلـة ولا نكـد" لمـاذا يـا مـوت وهـو لـيس بجاحـــ ولا نكـد فـلا انكـار منـه ولا جحـود، لمـاذا وأنـا في أشــد احتيـاجي لـه، إن فـي النـداء للمـوت ب "يـا"

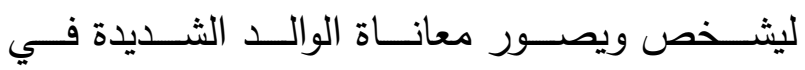
لحظـة حاجتهـ وعـوزه لابنـه، يـا مـوت لمـا غيبتـه يـا مـوت أجبنـي لمـا غيبتـهـ ؟ ألآ تعلـم حـاجتي لـه؟ إنهــا الحسـرة التـي تجسـدت وبـرزت فـي صـراخ عـال يثيـر المتلقــي ليصـرخ معـهـه ويشــاركه فـي صراخه على الموت لما غيب ولده؟. وينتقــل الثــاعر مـن الصــراخ والعويـلـل إلـى الترجسي فقـال :"يـا موتـهـه لـو أقلــ عثرتـهـ" فلـيس النـداء لومسا وعتابـا بقدر مـا رجـاء وترجي الثـاعر

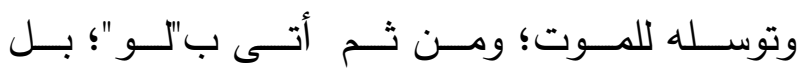

فبجوارك لا يعذب في قبره ،فهو يطلب منها أنت تكون حجابا وحارسا لولده، ثم يطلب منها اختراق

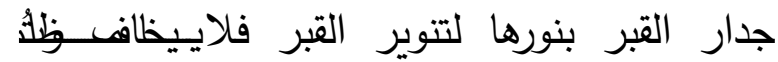
- (القبر

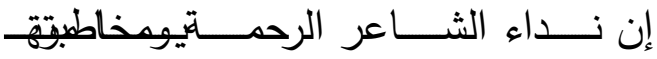

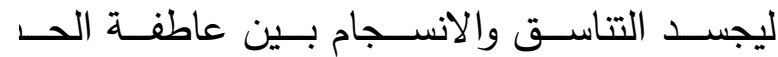
التـي تطلـب وتتمنـى؟ بـل وتلــح فيـيامجــلور. وتــوير التبـر ، وعاطفـة التحسـر والحـزن التـي مـ شـــتها لــم تتســه طلـب الرحمــة لابنــه؛ ومسـن ثـم فـالأمر فـي "جـاوري" لــهـ دلالـــة التمنــي وكـأن الثــاعر يتمنــى منــه رحمــة الله أن تجــاور جدثـهـ

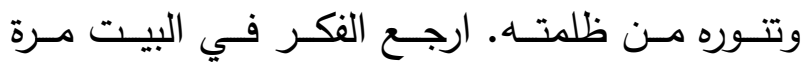
ثانيـة تلحـظ اســتخدام الثـاعر لكلمـة "جــثا" بــلا مــن القبـر تخفيـف مــن حجـم مصــيبته علـى الصــيد النفسـي هـذا مـن ناحيــة أن القبـر رديفــا

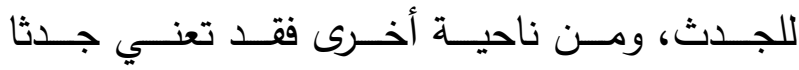
خاصــا فـي هضـــاب عاليــة ارتقــاء بمنزلــة ولـده علــى أقــلـ تقــدير دون أن يســاويه بغيــره مــن المــوتى؛ لأن الجــدث لغــة كمــا أرى فـي سـياقه اللغـوي أكثر رقيـا مـن القبـر ، وقـد يحمـل بعـدا ذا مسـتوى عـال للتعبيـر عـن نمـوذج إنسـاني متميـز وجـده الثــاعر فـي ولـده دون ســواه مـن النــاس كومـن ثـم أصـر الثـاعر علـى طلــب المجـاور للإعلاء من منزلة ولده حيا وميتا. 


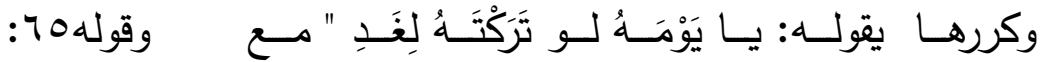

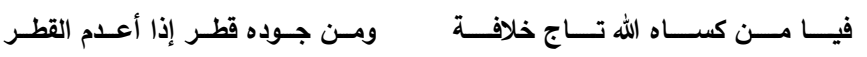

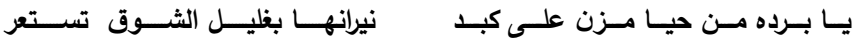
يـا عــاجزا لــيس يعفـو حـين يقتـدر ولا يفضــي لـهـ مــن عيثــه وطـر يـا مـن تلهـى وشـيب الـرأس يندبـه مساذا الـذي بعــ شـيب الـرأس ننتظر

قــ تكسـف الثـمس لا بـل يخسـف القمـ

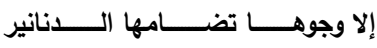
ينســيك أولــهـه فــي الحســن آخــره

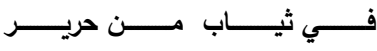

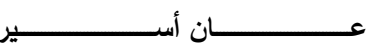

والمســــــ الجـــامع الـــني عـــر

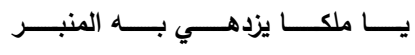

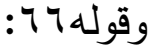

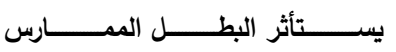

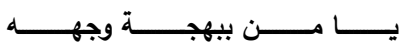
وقوله

مـــالي بعــــك بـــالعيش اعتبــــاط

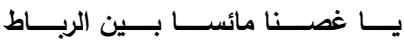

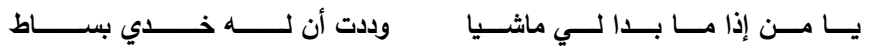

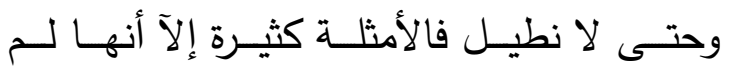

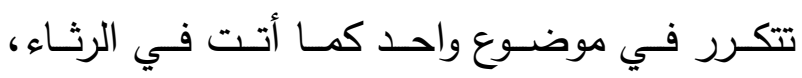

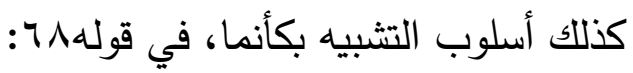

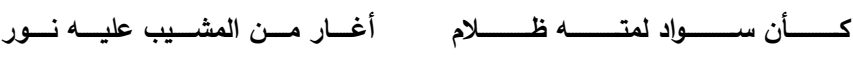

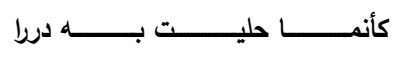

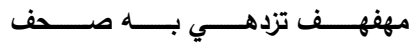
خــلال روض جنبــت بـــه الحـــرا

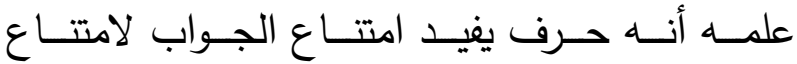
شـرطه فالإتيـان بلـو مكـررة جعل مسن المتمنى بـه أبعـد مــا يكـون و ومسـتحيلاً وقوعــه ، ومــع ذللك يناديـه وكأنـه يعـي محنتهـه ومصـيبته ويسـمع نـداءه فيجيبــه حيــث نــاداه بـ "يــا" المفيــدة للاســتغاثة، والثـاعر أراد مـن خـلال ندائه الذي يحمـل دلالـة

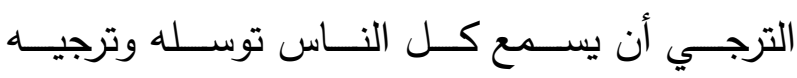
المــوت ويـبن لهـم حزنــه وألمــه ليشــاركوه همومــه وأحزانــه؛ ومسن ثـم يخفـف مسن وطـأة وشـدة الكـرب والجو المتأزم الذي هو فيه. ثـم يكـرر الثــاعر النـداء مــح لـو مـرة ثانيـة فيقـول :" يـا مــوتُ لــو لــم تكُنْ تُعاجلـهُ " وكـأن الشاعر يعاتب الموت لم تعجلت في أخذه؟. هـذا وقد تكـرر أسـلوب النـداء في ديـوان ابـن عبدربـه تـارة في المـدح وتـارة في غيـره كالتشـبيه بككأن بح إلا أنـه كـان أشـد تـأثيرا في رثائه لولـده كمـا بـين البحـث فـي تتاولـه وقـد اقتصـر البحـــ على النـداء في رثائهـ لابنــه خـوف الإطالـة وهـذه بعـض النمـاذج مـن أسـلوب النـداء فـي الـديوان، قولله

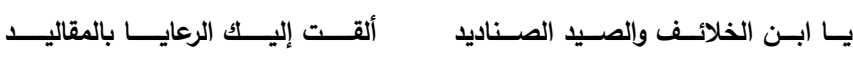
يــامن عليـــه رداء البــأس والجــود من جود كفك يجري المـاء في العود

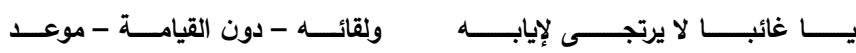

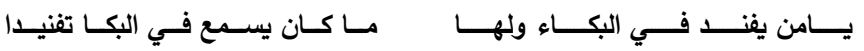


محـددة؛ ولكـن الاسـتفهام قـد لا يبحـث عـن إجابـة محددة؛ وإنمـا يبحـث عـن تصـور مـا للمـتكلم دون أن يستفسـر عـن شـيء ،وبهـذا يخــرج أسـلـوب الاســتفهام إلـى أســلوب مجــازي لا يطـابق فـي دلالتــه المجازيــة الدلالــة الحقيقيـة فيصـبح بمعنى الخبـــر لا بمعنـــى الاســـتخبار وحــين يخــرج الاسـتفهام إلىى أسـلوب مجـازي إنمـا يـؤدي ظـاهرة جماليــة لا تعـرف فـي الأســلوب الحقيقـي الـذي الذي

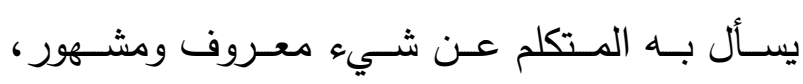

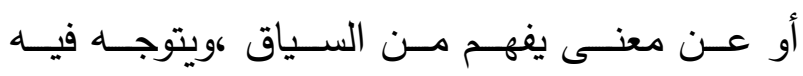

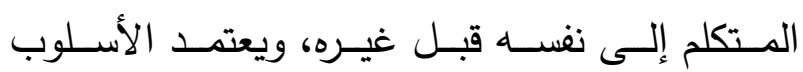
المجـازي علـى الســلائق والسـياق والقـرائن ويـدور حولها الكلام Vr.

وإذا كـان الاســتفهام فـي حقيقتــه السـؤال

عـن شـيء مجهـول V فـإنَّ شـعراء المراثي طالمــا أخرجـوه عـن معنــاه الأصــلي إلـى معــانٍ تســفاد مـن السـياق، فكـان يعبـر عـن تجـاربهم الثـعورية، ويـدل علـى معــاني الــذهول والتفجـع، كمــا نـراه يخـرج الاسـتفهام عـن أصـله لأغـراض أدبيـة منهـا:

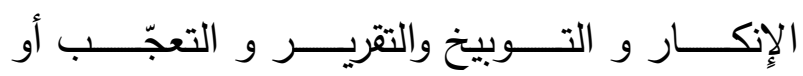

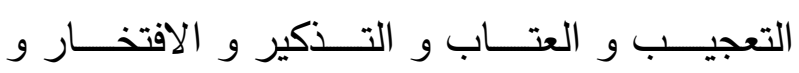

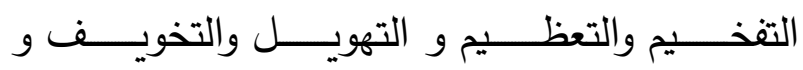

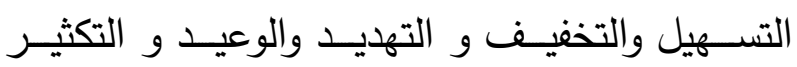

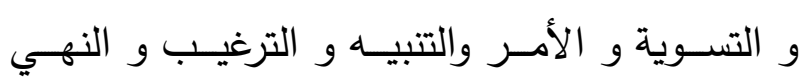
جr Pماليات الخبر والإنشاء "دراسة بلاغية نقدية" حسين جمعة، اتحاد

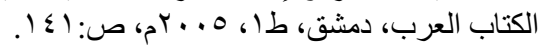

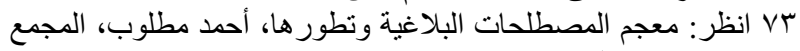

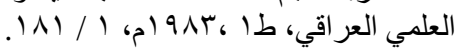

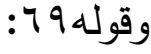

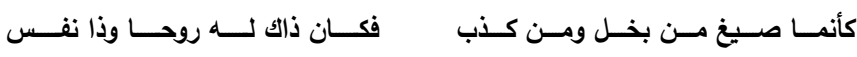

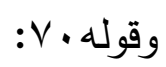

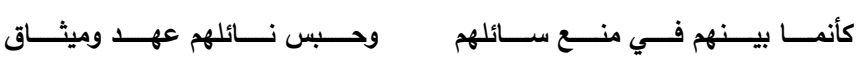

$$
\begin{aligned}
& \text { وهكــذا تتوعــت الأســاليب فــي ديــوان ابـن }
\end{aligned}
$$

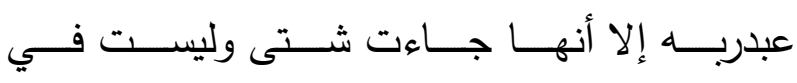

$$
\begin{aligned}
& \text { موضوع واحد كما في الرثاء. } \\
& \text { ـ تكرار أسلوب الاستفهام: }
\end{aligned}
$$

يُعــٌٌُ أســلوب الاســـفهام مــن الأســـاليب

اللغويـــة والبلاغيــة التــي تضــفي علــى دلالــــة

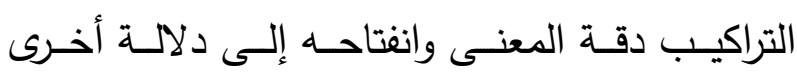
تعتمـل في الـنفس وصــلاً إلـى إثـارة فكـر القـارئ، فهــو بمثابـة المثيـر الــني يحفـز العقـل بمداولــة النظـر ، والتفكـر بماهيتـهـ الأشـياء والوقـوف عليهـا؛ فيحـدث الاسـتفهام نوعـا مـن التفاعـل بـين السـائل والمسئول ،فتظهر الخفايا لv) وقـد أبـرز البلاغيـون العـرب في الدراسـات

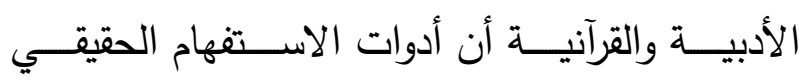
الـذي تتوقف عنــ المعـاني الأصـيلة التي ينتهـي إليهــا أسـلـوب الاسـتفهام الحقيقـي يتطلـب إجابــة

$$
\text { • }{ }^{9}
$$

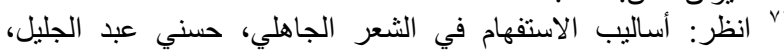

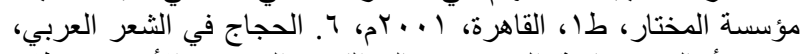

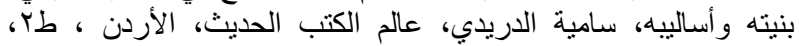

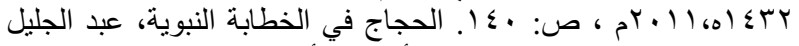

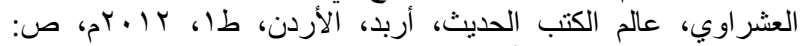

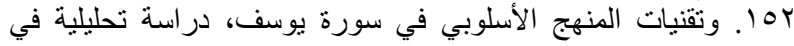

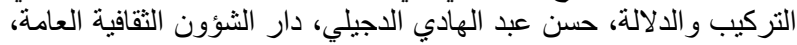

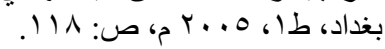


حـدث لـهـ مـن فاجعــة في عزيـز عليـه أو فـي واقعـة مـا، وأيّّ: اسـم اسـتفهام، وتـأتي على أوجـهِ، منهـا: الاسـتفهام، إذ قيـل: و" ترفـع علـى الابتـداء إذا لـم يعهـل فيهـا شـيء، ومـا بعدها خبرهـا، وقيـل أيضــاً: تتصــب بالفعـل الـذي بعـدها نحــو : أيّهـم

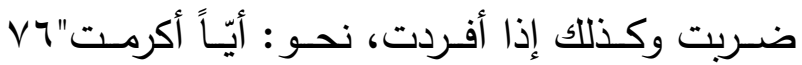
و (أيّي) الاسـتفهاميّة لا يعمـل فيهـا مــا قبلهــا مـن الأفعـال؛ لأنبّ الاســتفهام لــه صــدر الكـلام، قــال ســيبويه فـي معناهــا:" أيّ مكــان، وهـي تجــري مجـرى "مـا" فـي كـلّ شـيء" VV، وذكـر المـرادي

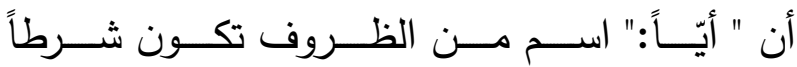

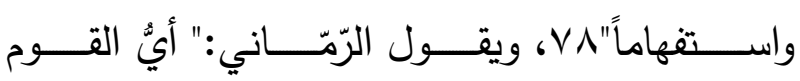
عندك؟ وأَيَّهم ضــربت؟ وبـأيهم مـررت؟ وإذا كانــت استفهاماً عمل فيها مـا بعدها، ولـم يعمل فيهـا مـا

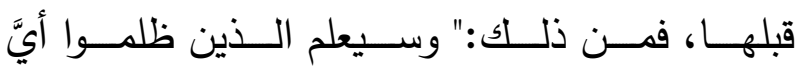
منقلـب ينقلبـون" V9 تتصــب أيـاً بـ" ينقلبـون "، ولا يجـوز نصـبـها بـ "سـيعلم"؛ لأن الاسـتفهام لا يعمـل

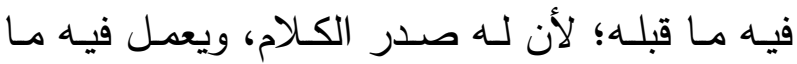
بعـده؛ لأنسه لا يخرجـه مـن الصــدر في اللفظظ" ــ.

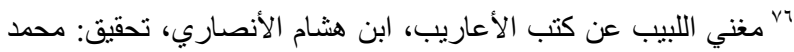

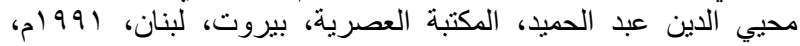

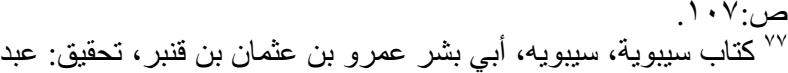

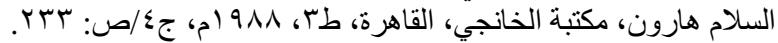

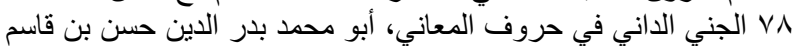

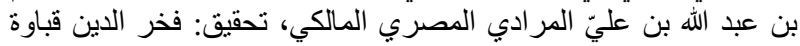

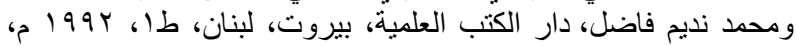

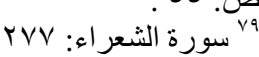

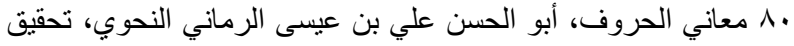

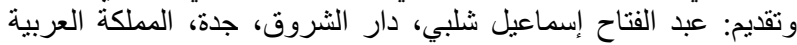

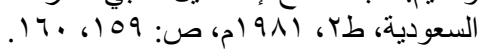

و الـــدعاء و الاسترشــــاد و التَّنّّــي والترجّــي و الاســتبطاء و العــرض و التحضــيض و التجاهـل و التحقيـر والاســتهانة و المـدح والـذّم و الاكتفــاء

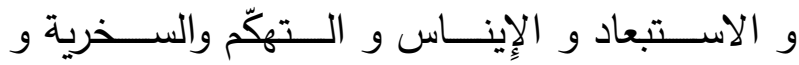
الإخبـار و التأكيـد. إلـى غيــر ذلـك مـن معـادنٍ،

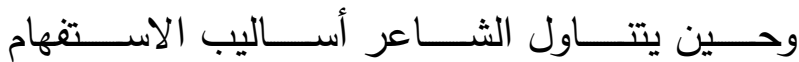
المجازيــة التـي انتهـت إلـى عـدول أو مـا يسـمونه حـيثا انزياحسا في التركيـب وفي الدلالــة لابـد مـن استحضــار الــدوافع وراء ذلــلك الاســتعمال، عنــد

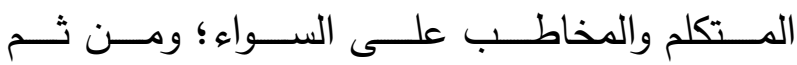
استحضــار الجــو النفسـي والاجتمــاعي والفكــري والزمنـي الـذي اضـطر الشـاعر لـذذا العـدول في

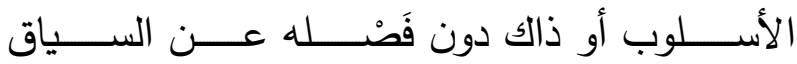
النصـي الذي يرمسي إلـى هـدف مـا. ولعـل المعانـاة الحقيقيـة والفهــم الـدقيق لأســلوب مــن الأســاليب يسـاعدان في إنتـاج جماليـة جديـدة ومبدعـة لقـراءة نص من النصوص ع V. ولنقـرأ أسـلوب الاسـتفهام فـي رثـاء ابـن عبـد ربـه لابنه، إذ يقول

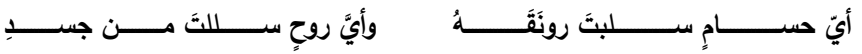

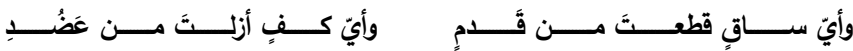
إذا كـان التوجـح والتـألم والتحسـر مـن أغـراض أســلوب الاســتفهام البيانيــة والتــي يقصد الشـــاعر في مقـام يـظهر فيـه الثـاعر حزنـه وألمـه الذي لمـا

ع البلاغة العربية أسسها و علومها وفنونها، عبد الرحمن بن حسن حَبَنَّكَة

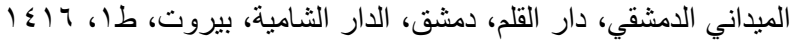

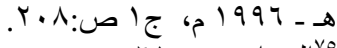

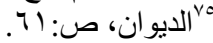


يعـرض عليـه حالتـهه مـن الحيـرة والضـعف والحـزن والتألم لموت ولده كثم يعود فينادي ولده ام:

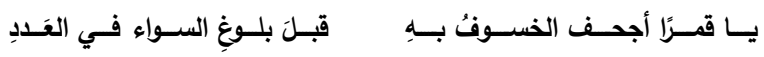

ثـم يعـود ثانيـة مسـتفهما ومتعجبـا ومسـتنكرًا، أي حشـا هـذه التـي لـم تشـاركني فجيعتـي؛ بـل وأي

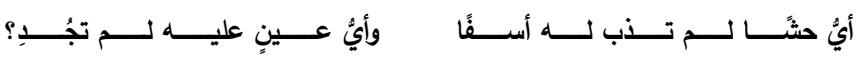

ويعـدل الثـاعر مـرة أخـرى لنـداء اللوعـة والحرسـة،

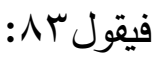

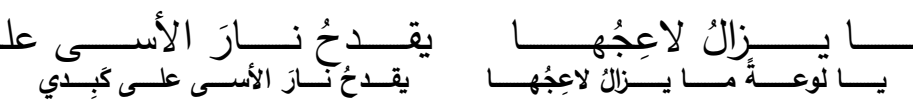
يميـل الثـاعر فـي كثيـر مـن أبيـات الـديوان إلـى أزواج شـتى مـن التكـرار كالأفعـال والأسـماء والأسـاليب وغيـر ذلـك مسن أزواج التكـرار ؛ فتشـكل

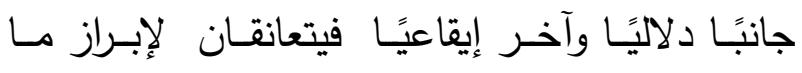

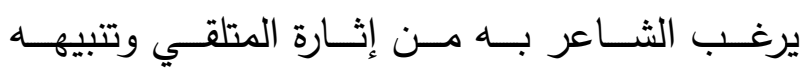

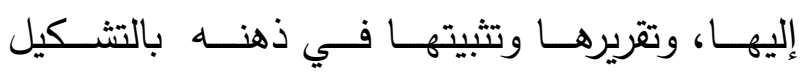
الايقـاعي الصــوتي فيحـدث الاتسـاق والانســام

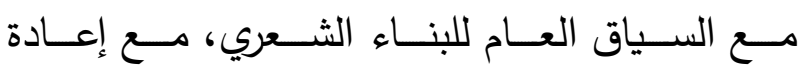

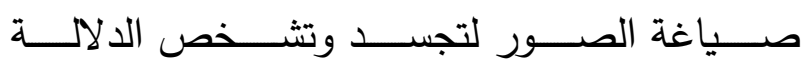

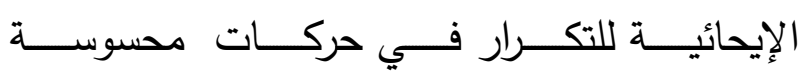

تكــررت أداة الاســتفهام "أي" أربـــع مــرات فـي البيتين فهل الدلالة واحدة ؟.

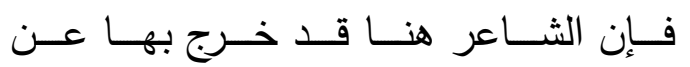

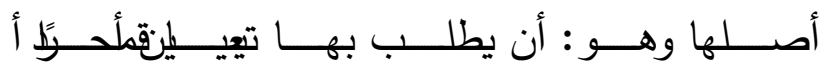

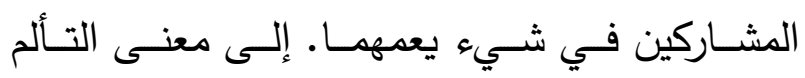

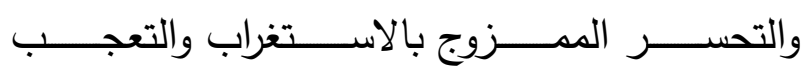

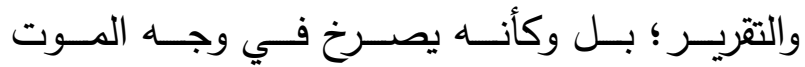

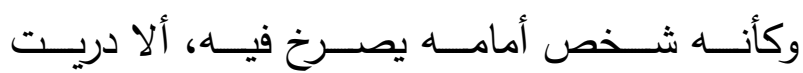

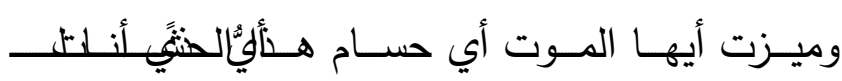
سـلبت رونقـهـ مـن حيـاتي إنـا ابنـي حسـام حيـاتي

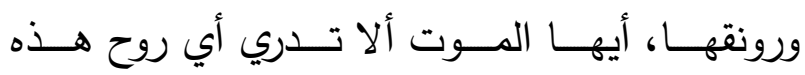
التـي سـللتها مـن جســ إنهـا روحـي" إنــه ولـدي"،

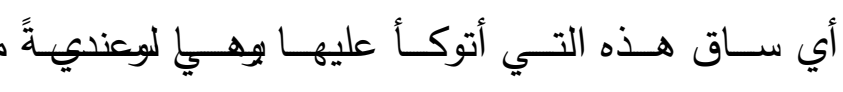

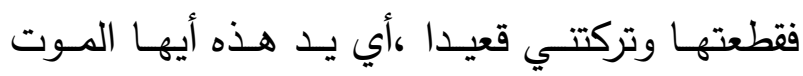

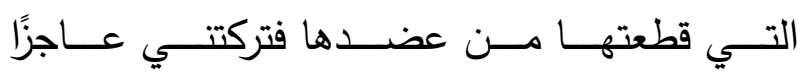
ضنعيفًا . إن الفجيعــة والحــزن والتــألم والحســرة علـى

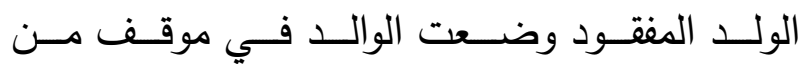

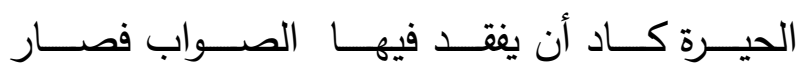
صـارخا مندهشـا مسـتنكرا غيـر معتـرض ،وكأنـهـ يعــرض صـــورته البائســـة بعــدما سـلبت أيهـــا

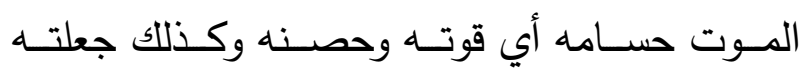
جسـدا بـلا روح كمــا أقعدتـه وبتـرت يـده ألا كنــ رحيما أيها الموت؟. إن الشــاعر باســتخدامه أســلوب الاســـفهام

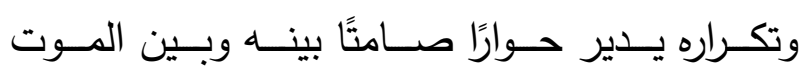


للمتلقـي ناقلـة فاجعـة الأب فـي ابنــه. وهـــا لـون

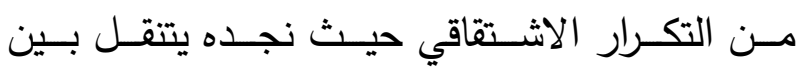
الاســم بمعانيــهـ الدالــة علــى الاســتقرار والثبـات والفعـل الدالـة معانيـهـ علـى الحركــة والاسـتمرارية

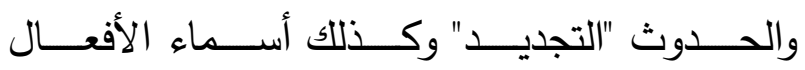
والصـفات المشـبهة وغيرهـا التي تشـكل دورا بـارزا ومهمــا في اتسـاع دائـرة مقاصـــ الثـاعر الدلاليـة والإيحائيــة وتوضـيحها وتتثيتهـا فـي فكر المتلقـي وخياله، ومن قول ابن عبد ربه في ذلك بلهي

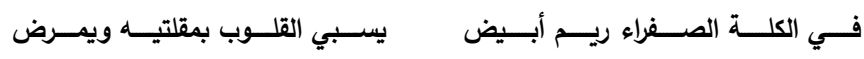

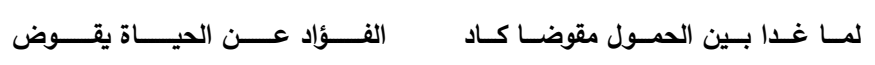

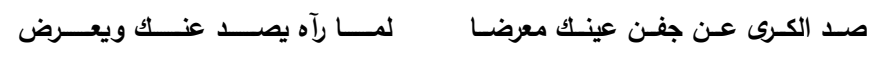
أديـــت مــن حبــي إليــك فريضـــة إن كــان حـب الخــق ممــا يفـرض ارجـع بصـر التـدبر فـي التكـرار الاثـتقاقي

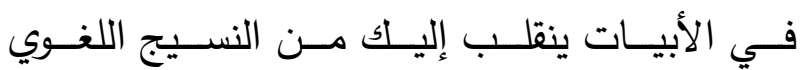
والاتســاق بـين التركيــب الاســمي المعبـر عـن الثبـات وحركيـة واسـتمرارية الأفعـال فـي تثـكيل لوحسة فسـيحة تعبيريــة للملقـي المنفعـل والمتلقـي

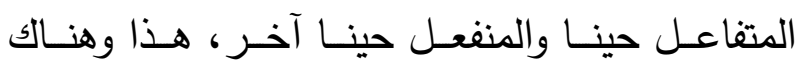
ازواج أخـرى مـن التكـرار لـدى الثـاعر تقـوم على

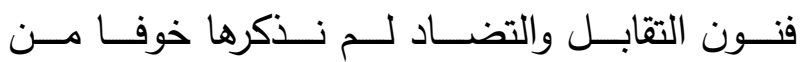

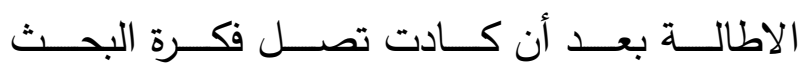
للمتلقي.
متعـددة الـنغم الموسـيقي ومختلفــة الألــوان، كمــا يـرى فيهـــا المتـذذوق قــدرة الثـــاعر الفنيــة فــي التناسـق بـين الجانـب الـدلالي والجانـب الإيقـاعي "الصوتي" أو الموسيقي، من ذللك قولهـ^م:

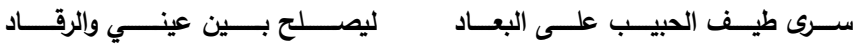

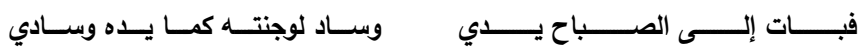

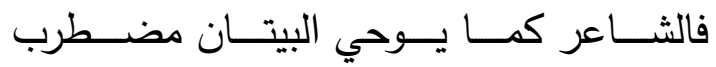
الـنفس، فبحـث عـن سـكينة وطمأنينــة استحضـرها مـن عـالم الخيـال لطيف محبوبـة لينهي مـا بـه مـن جفـاء بــين عينيـهـ والرقـاد، ويـأتي التكـرار "يـدي

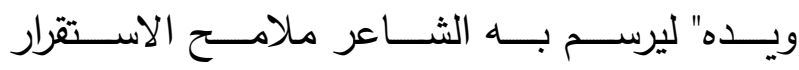
المفقـود؛ ومــن ثـم كـان التكــرار تعويضًَــا إبــاعيًا هدفــه تحقيـق غــرض الثـــاعر المفقــود، وكــللك قوله الهم:

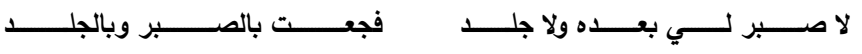

فـالتكرار " لا جلـد والجلـد" أســـم فـي تجسـيد وتثـخيص الواقـع المـؤلم لـدى الثـاعر لفقده ولـده، فتكـرار "الجلـد" في صـدر البيـت وعجزه مـع النفي رسـمت أكبـر قـدر مـن المشـاعر العاطفيـة المثقلـة

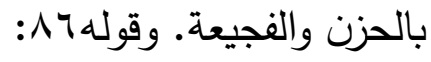

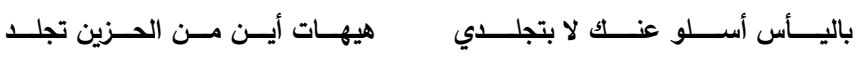
فـالتكرار فـي هـذا البيــت وإن كـان مقصـودًا مــن الشــاعر إلا أن عواطفــهـ الحزينـــة تســـيطر عليــه وتقــوده فـي مهــارة فنيــة؛ لتصــل أســراره 
المتلقـي قــدرة إفهاميــة تكســبه موهبــة اســتجلاء الألفاظ وفهم دلالاتها. كــرر الثـــاعر بعـــ الأدوات كأســلوب

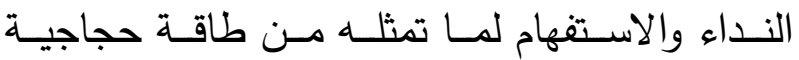

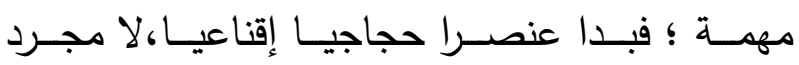

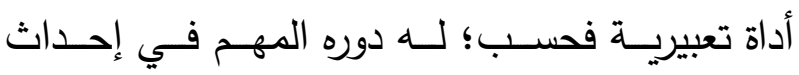

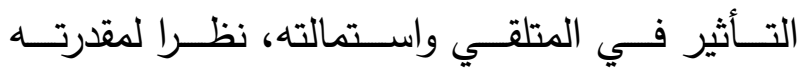
الكبيرة على الإيحاء والحث.

\section{المصادر والمراجع}

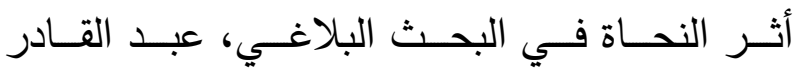

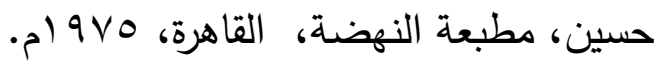

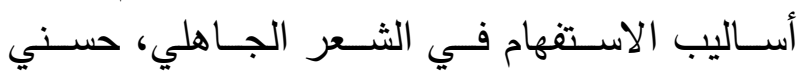

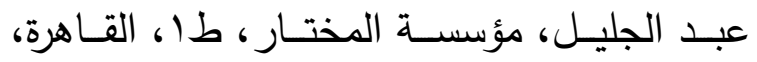

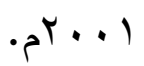

أســرار التكــرار فـي لغــة القـرآن، محمــود السـيد

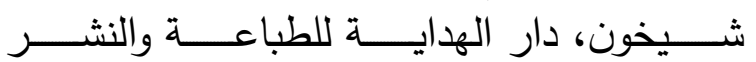

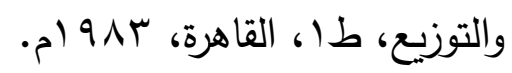

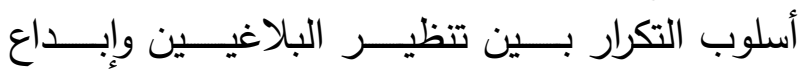

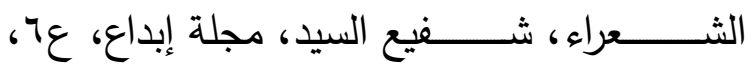
. $191 \varepsilon$

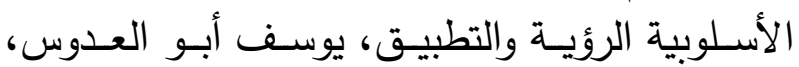

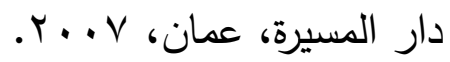

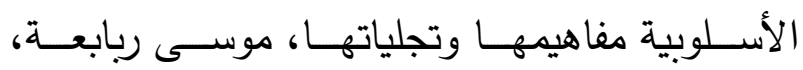

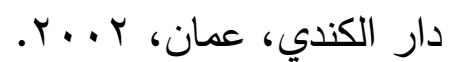

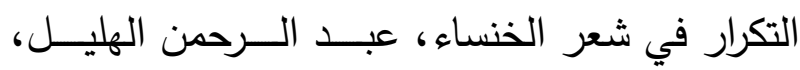

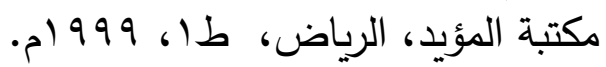

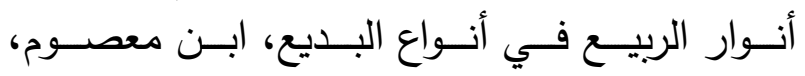

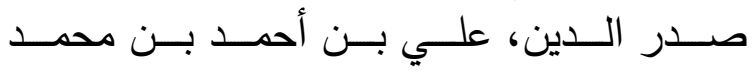

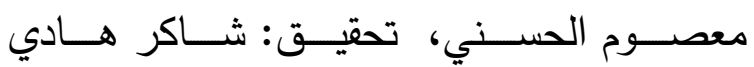
شكر ، مطبعة النعمان، العراق، جه تهون

\section{الخاتمة}

خلصت الدراسة إلى ما يأتي:

ليس التكـرار مجـرد إعـادة ذكـر كلمــة معينـة

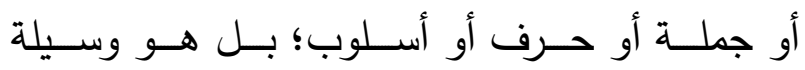

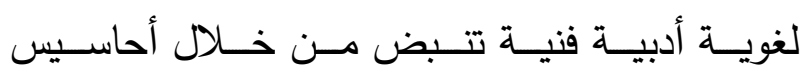

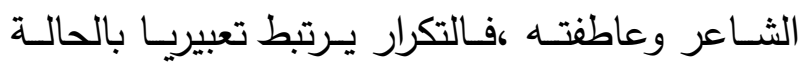

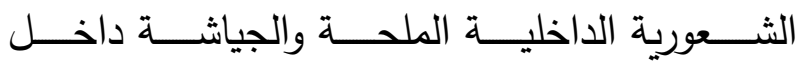

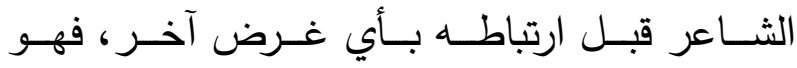

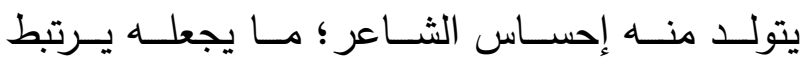
بالوظيفة الانفعالية أيما ارتباط.

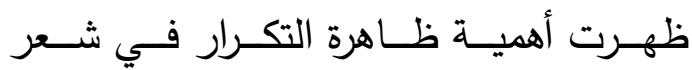

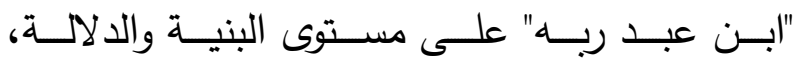

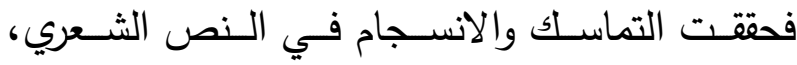

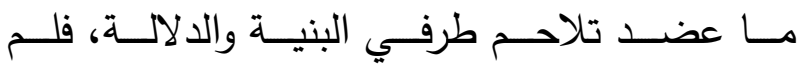

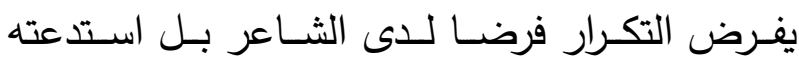

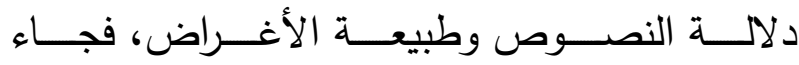
ملتحمـــــــل عناصــر الـنص الفنيـة مرتبطــا بهـا

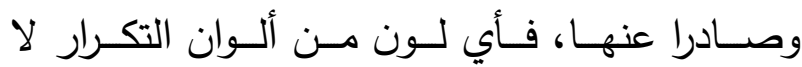

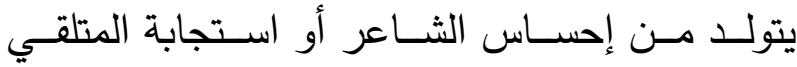

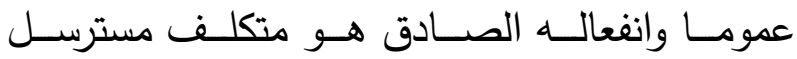

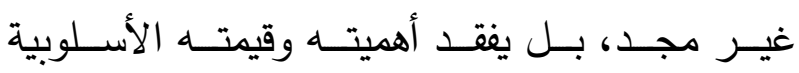
ويصبح تكرارا مملا وعبئًا على النص.

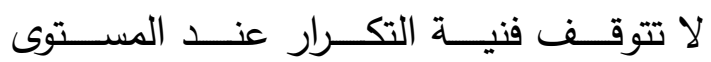

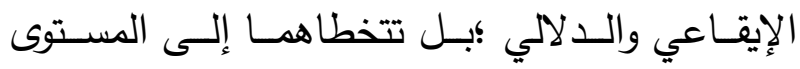

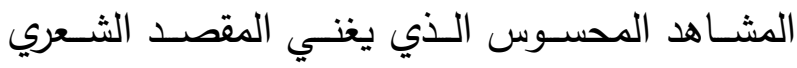
ويعـزز حضــوره فــي البيــ؛ ومـن ثـم يعطـي ليطي 
ثـلاث رسـائل فـي اعجـاز القـرآن، تحقيـق: محمــ

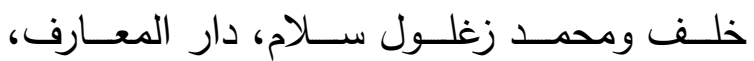
مصر - مص

جماليـات الخبـر والإنشــاء "دراســة بلاغيــة نقديـة"

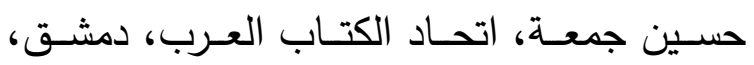
طا، 0 . .

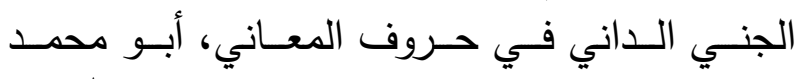

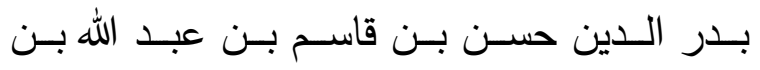
علــيّ المــرادي المصــري المـــالكي، تحقيــق فخـر الـدين قبــاوة ومحمــد نــديم فاضـلـ، دار

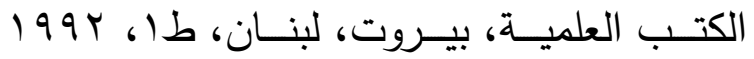

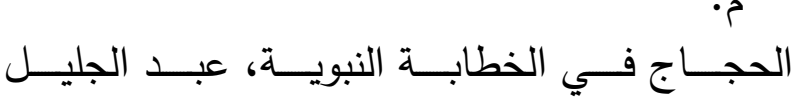

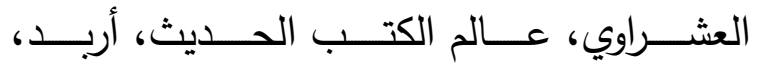

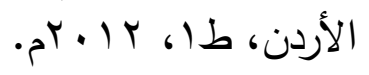

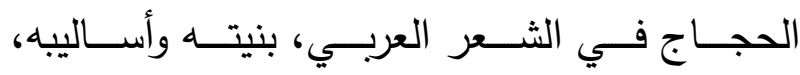

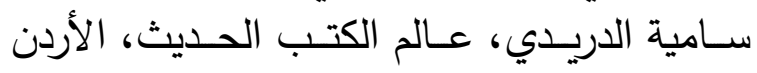

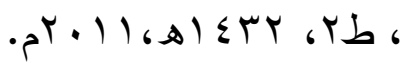

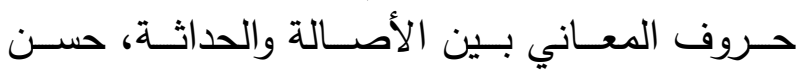

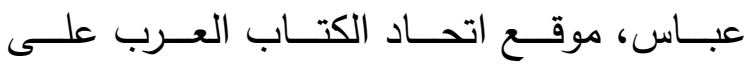

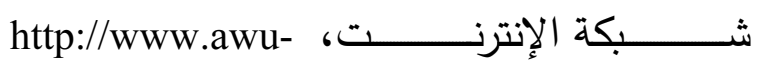
.dam.or الحيـوان، عمـرو بـن بحـر بـن محبـوب الكنـاني،

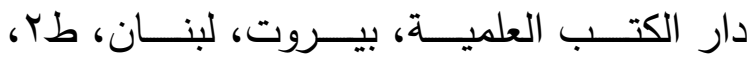
هـ $\leqslant$ (ه خزانــة الأدب ولـب لبـاب لســان العـرب، تحقيـق:

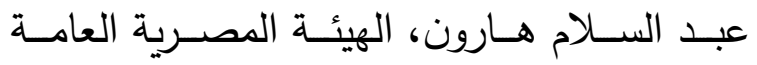

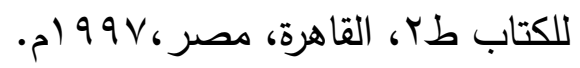

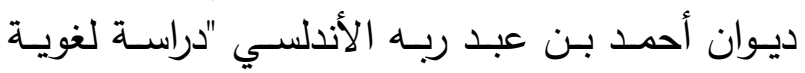

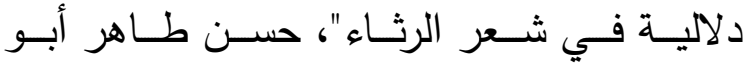

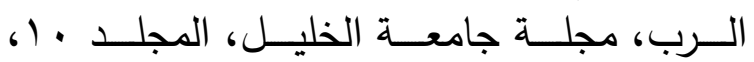

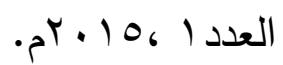

البـديع في القـرآن أنواعـه ووظائفـه، إبـراهيم محمـود

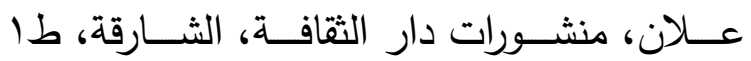
.$r^{r} \cdot r_{6}$

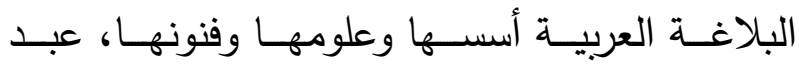

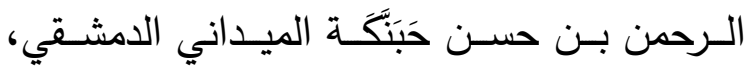

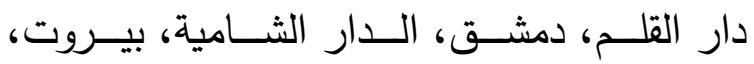

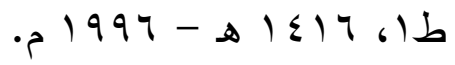

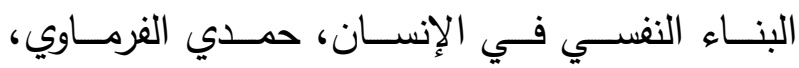
مكتبة زهراء الشرق، 999 (م. 99

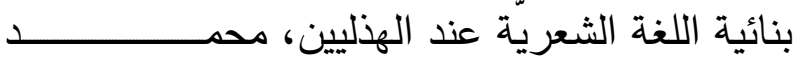

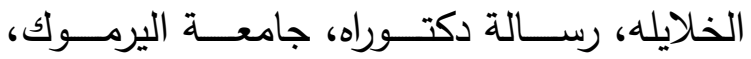

$$
\text { • } 1
$$

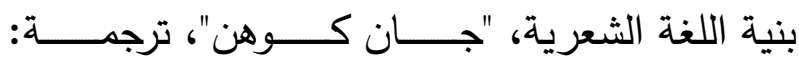

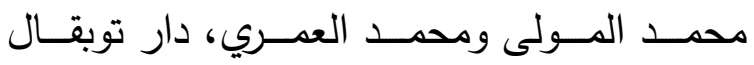

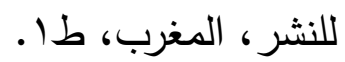

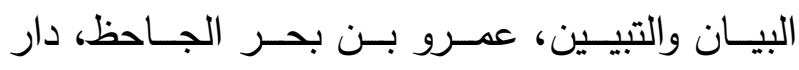

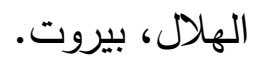

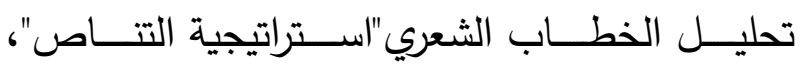
محمـد العــري، المركـز الثقــافي العربـي، الـدار

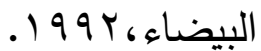
التصــريف فـي الــنظم القرآنــي دراســـة بلاغيــة

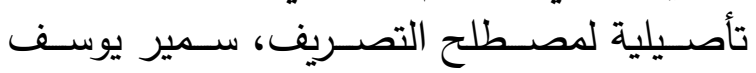

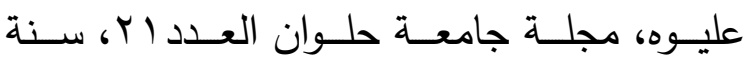
r. . V

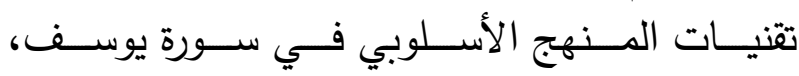

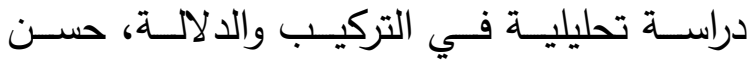

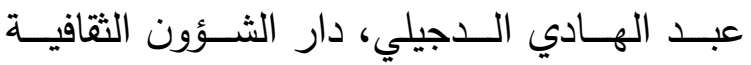

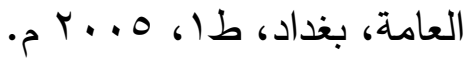

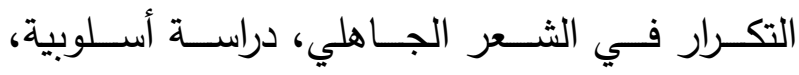

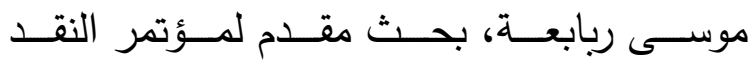

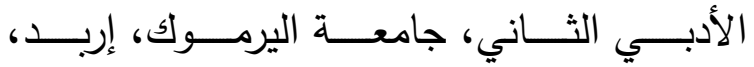
- م) $9 \wedge 1$ 


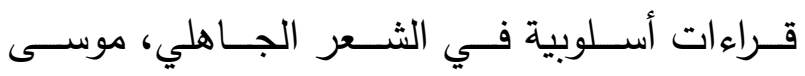

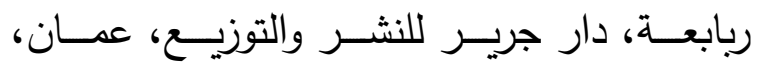

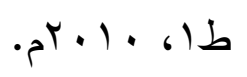

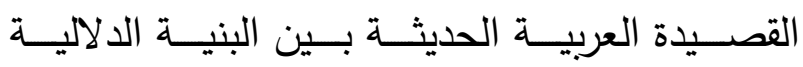

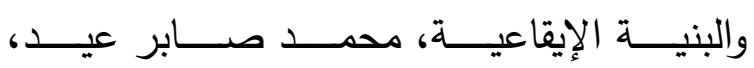

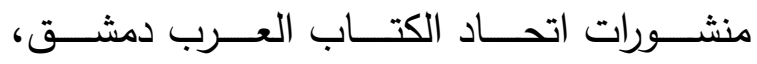
. 199 r قضــايا الثــعر المعاصــر ، نـــازك الملائكــة، دار

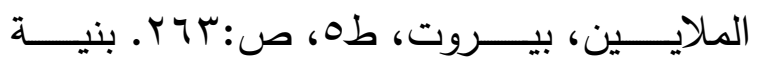

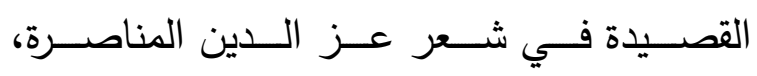

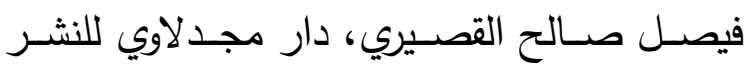

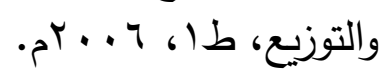

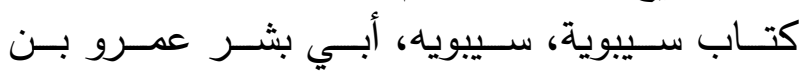

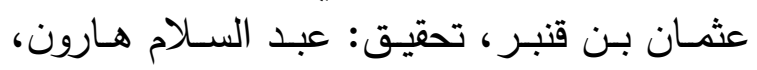

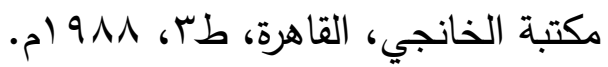

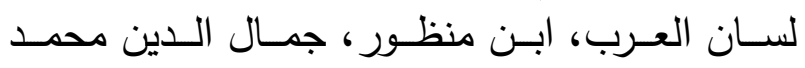

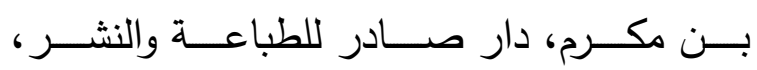

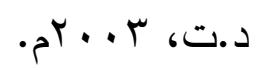

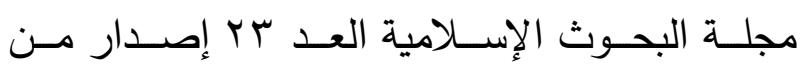

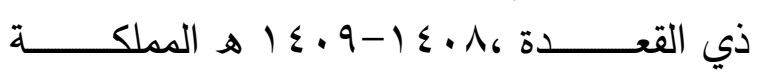

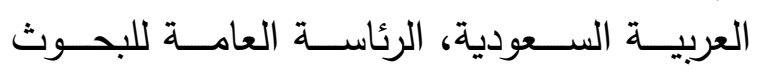
والافتاء.

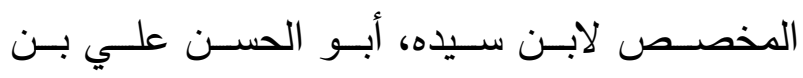

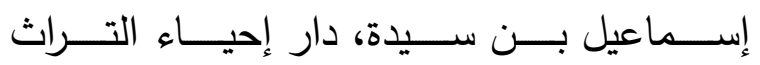

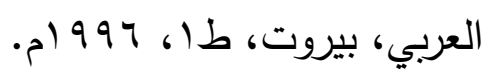

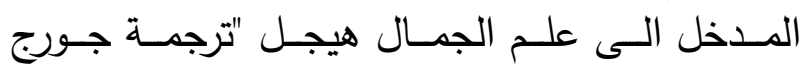

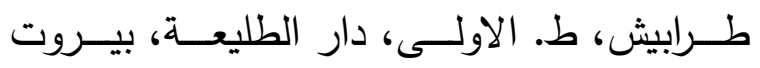
. 9 ) 9 人

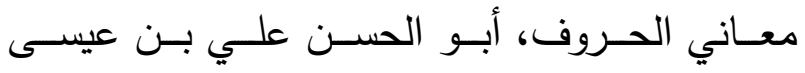

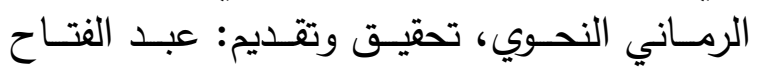

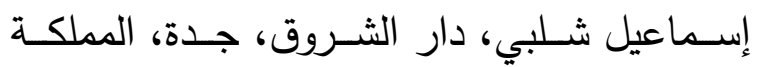

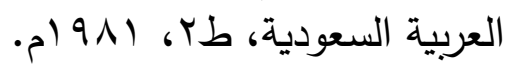

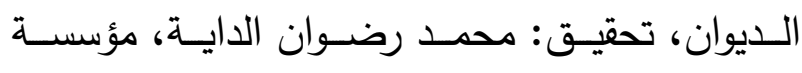

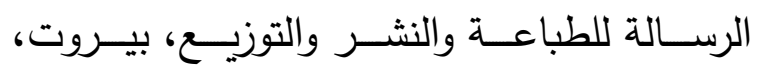

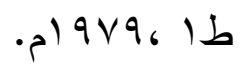

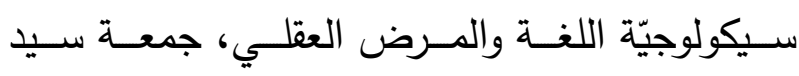

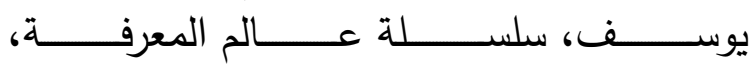

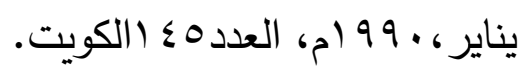

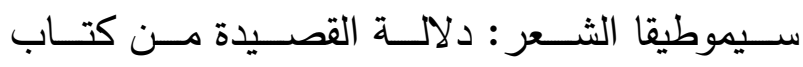

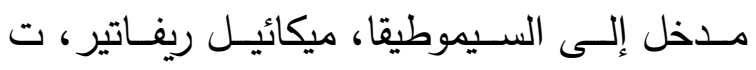

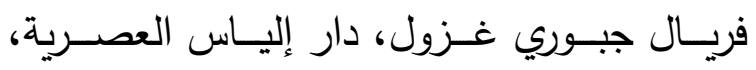

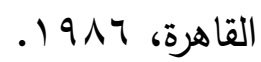

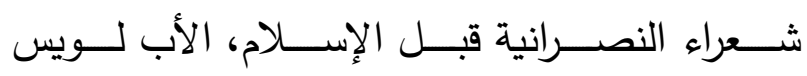

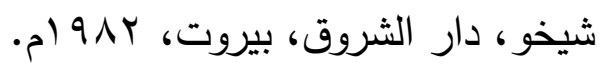

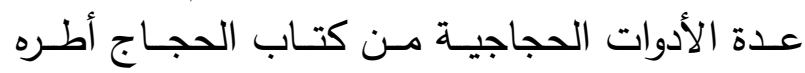

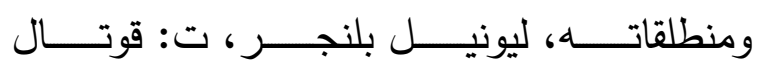

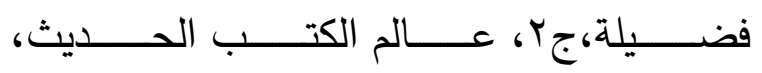

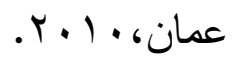

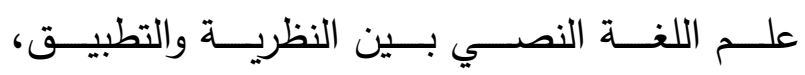

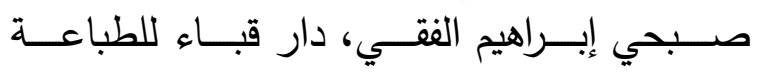

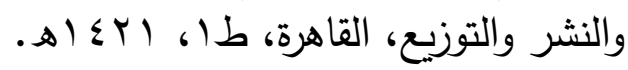

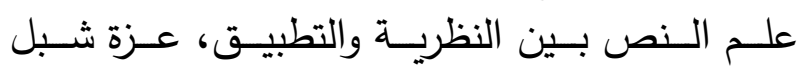

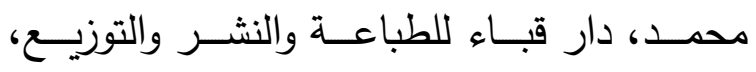

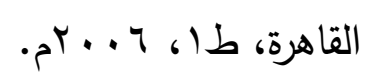

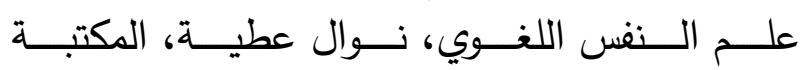

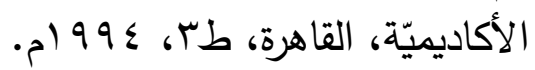

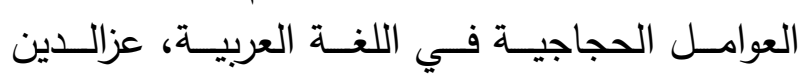

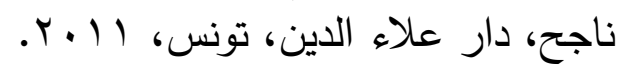

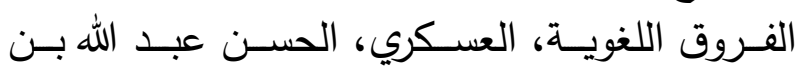

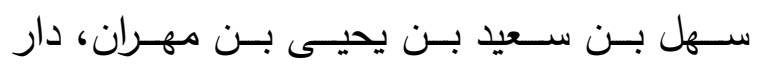

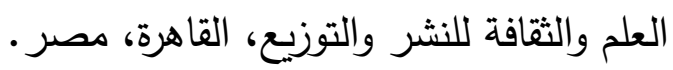

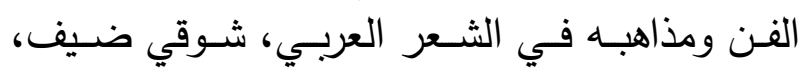

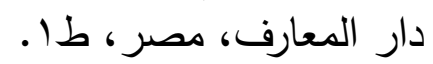


مغنـي اللبيـب عـن كتب الأعاريـب، ابـن هثـام

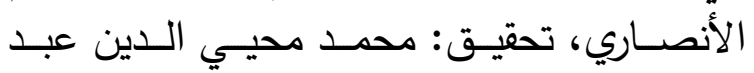

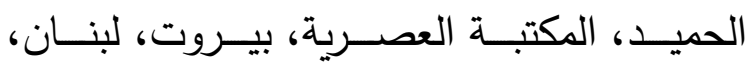
.

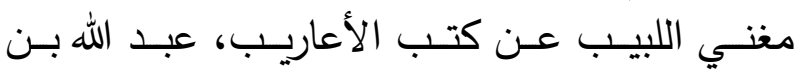

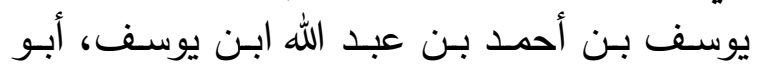

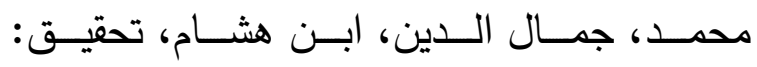

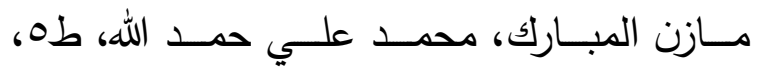

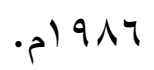
المنـزع البـديع في تجنيس أسـاليب البـديع، لأبسي

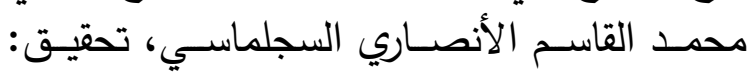

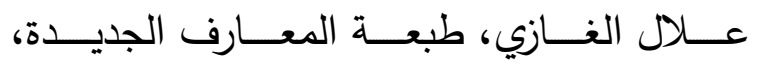

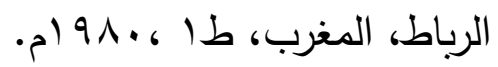

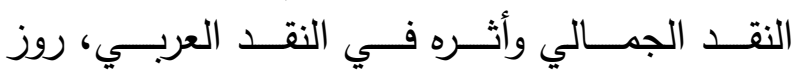

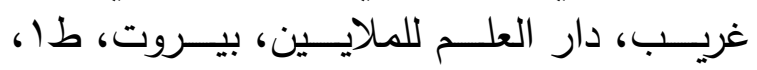

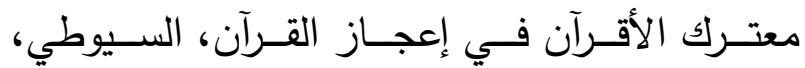
دار الفكر العربي، بيروت، لبنان.

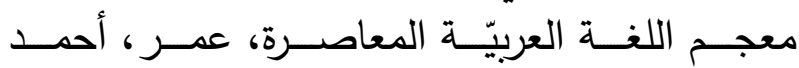

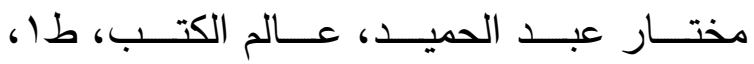

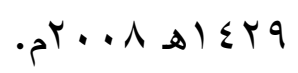

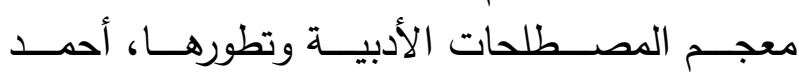

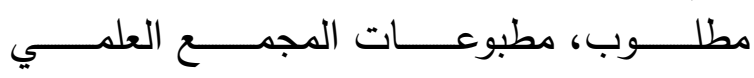

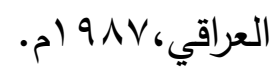

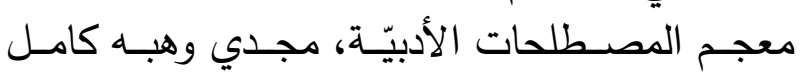
المهنس، مكتبة لبنان.

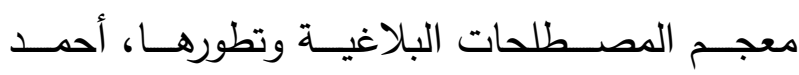

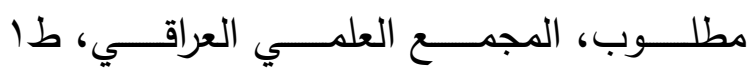

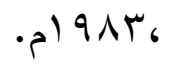

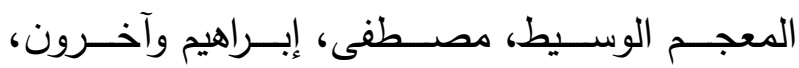

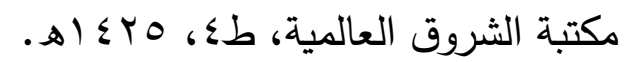




\title{
Repetition in Ibn Abdrabuh's poetry Technical study
}

\author{
saleem said alsulami \\ University of Tabuk
}

\begin{abstract}
The variety of repetition in Ibn Abdrabuh's poetry has useful and great influence in showing his poetic creativity. The poet tries to avoid ornate style and decorative linguistic devices, and this makes him seem inherent rather than adventitious poet. This characteristic is very clear through discussing the style of repetition in his elegies, eulogies, or his other poems. In fact, studies were written about repetition in Ibn Abdrabuh's poetry are a lot, but they are not organized. As a result, the researcher use his experience to explore how brilliant was Ibn Abdrabuh when he uses repetition in his various poems.
\end{abstract}

